\title{
Theresienstadt: A Geographical Picture of Transports, Demography and Communicable Disease in a Jewish Camp-Ghetto, 1941-45
}

\author{
Matthew R Smallman-Raynor ${ }^{\mathrm{a}}$ and Andrew D Cliff ${ }^{\mathrm{b}}$
}

$\underline{\text { Positions and affiliations }}$

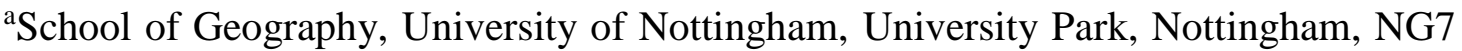
2RD, UK. email: matthew.smallman-raynor@nottingham.ac.uk .

bepartment of Geography, University of Cambridge, Downing Place, Cambridge, CB2 3EN, UK. Email: adc2@cam.ac.uk.

\section{Correspondence}

M R Smallman-Raynor, School of Geography, University of Nottingham, University Park, Nottingham, NG7 2RD, UK. Email: matthew.smallmanraynor@nottingham.ac.uk. Tel.: +44 (0)1159515427.

Acknowledgements

This work was supported by a grant from the Leverhulme Trust (RPG-2012-736).

Declaration of interest

None. 


\section{Abstract}

The Nazi ghetto system was one of the principal vehicles for the persecution of Jewish and other peoples in German-occupied Europe in World War II. Transport and confinement - twin pillars of the ghetto system - were intrinsically geographical matters that operated on scales from the international to the local and which shaped the demographic and epidemiological character of ghettos across Eastern Europe. This article uses geographical techniques of map-based visualisation and spatial analysis to portray the demographic and epidemic history of the Nazi 'model' camp-ghetto at Theresienstadt (Terezín) in the former German Protectorate of Bohemia and Moravia, 1941-45. Our study reconstructs the space-time pattern and demographic structure of transports of Jewish prisoners to the ghetto and their association with substantial outbreaks of communicable diseases in the ghetto. The study highlights the importance of a geographical approach to an understanding of the demographic and public health impacts of both the Holocaust and other genocidal events. 


\section{Introduction}

The Nazi ghetto system was one of the main vehicles for the persecution of Jewish and other peoples in German-occupied Europe in World War II (Michman and Schramm 2011). The ghetto system extended across a swathe of Eastern Europe and consisted of thousands of urban districts and other locations - the exact number is still uncertain in which Jews and others were confined for the purpose of segregating them from the rest of the population (Megargee and Dean 2012; Megargee et al. 2018; Miron 2010). The first ghetto was established at Piotrków Trybunalski, Poland, in October 1939. Thereafter, large metropolitan ghettos were established in many cities of Germanoccupied Eastern Europe, notably in Lódź and Warsaw in 1940, Białystok, Kraków, Lwów, Minsk, Riga and Vilna in 1941 and, somewhat later, Budapest in 1944 (Cole 2003; Epstein 2008; Gutman 1982; Horwitz 2008). The systematic liquidation of the ghettos began in the winter of 1941-42 with the implementation of the Final Solution, resulting in the death of millions by way of immediate killings and mass deportations to the death camps at Auschwitz, Bełżec, Chełmno, Majdanek, Sobibór and Treblinka (United States Holocaust Memorial Museum 2015a).

In their book Geographies of the Holocaust, Anne Kelly Knowles and colleagues observe that the Holocaust was "a profoundly geographical phenomenon, though few scholars have analyzed it from that perspective" (Knowles et al. 2014: 1; see also Charlesworth 1992). Transport and confinement - twin pillars of the Nazi ghetto system - were intrinsically geographical matters that operated on scales from the international to the local and which shaped the demographic and epidemiologic character of Jewish ghettos across Eastern Europe (Gilbert 2009; Knowles et al. 2014; Megargee and Dean 2012; United States Holocaust Memorial Museum 1996). In this paper, we use geographical methods of map-based visualisation and spatial analysis to 
aid an understanding of the intrinsic links between the demographic and epidemic histories of the 'model' camp-ghetto at Theresienstadt (Terezín in Czech) in the erstwhile German Protectorate of Bohemia and Moravia (Figure 1). ${ }^{1}$ Our study presents the first detailed graphical reconstruction of the geographical pattern of transports of Jewish prisoners to the ghetto, their shifting demographic structure and their association with outbreaks of communicable diseases that were carried through Theresienstadt's demographic revolving door - the Schleuse ('floodgate'). We show how, in the highly controlled environment of Jewish prisoner transports from cities across Nazi Europe to the ghettos, and then on to the extermination camps, communicable diseases travelled with the prisoners and contributed to the Holocaust's turbid mix of illness and death.

\section{FIGURE 1 NEAR HERE}

Theresienstadt was the last of the substantially populated Nazi concentration camps and ghettos to be liberated by the Allies (May 8, 1945); see Stone (2015). ${ }^{2}$ The present study is a contribution to commemorations of the 75th anniversary of that historic event. The study is informed by recent scholarship on aspects of medicine,

1 The Protectorate of Bohemia and Moravia was established in mid-March 1939, following the German occupation of Czechoslovakia at that time. Today, Theresienstadt is located in the northern part of the Czech Republic, near the city of Litoměřice and about $65 \mathrm{~km}$ north of Prague; see Figure 1.

2 The Theresienstadt camp-ghetto has attracted a large literature, some of which is in the Czech language and much of which is beyond the immediate scope of the present study. See Blodig and White (2012: 182-4) and Terezín Memorial Library (www.pamatnik-terezin.cz/library; accessed May 23, 2019) for overviews of the range of literature. 
health and disease in Theresienstadt (Horáčková et al. 2017) and by a recognition that the medical histories of those interned in the ghettos have been largely overlooked in Holocaust research (Hájková 2018). Our study is also informed by an increasing public health concern with genocidal violence as "one of the most pressing threats to the health of populations in the twenty-first century" (Adler et al. 2004: 2028. See also: Fein 1997; Krug et al. 2002; Willis and Levy 2000). Mass population dislocation and communicable diseases are - by accident or design - frequent manifestations of such violence (Smallman-Raynor and Cliff 2018: 242-69). Our study highlights the importance of a geographical understanding of the intersection of these factors when attempting to comprehend the demographic and public health impacts of genocidal events.

\section{Background: The Theresienstadt 'Model' Camp-Ghetto}

Theresienstadt ghetto was established by the Nazis in the main fortress of the garrison town of Theresienstadt in November 1941 (Figure 1). Perspectives on the ghetto, its organisation and daily life are provided in the survivor accounts of Lederer (1953), Adler (1955, 2017) and Troller (1991). As the term 'camp-ghetto' implies, Theresienstadt was a hybrid space that differed in kind from the major urban ghettos of Warsaw, Lódź and elsewhere in German-occupied Eastern Europe (Megargee and Dean 2012). As Blodig and White (2012) observe, Theresienstadt functioned as a reception, holding and transit camp and this has led some observers to view it as a form of 'concentration camp'. On the other hand, the forced removal of Theresienstadt's non-Jewish Czech inhabitants by June 1942 was consistent with its commonly-held status as a 'ghetto' (Blodig and White, 2012: 180). More generally, Prochnik (1945: 6) has divided the history of Theresienstadt under Nazi control into 
four broad phases: (i) Arbeitslager or 'labour camp' (November 1941-June 1942); (ii) Ghetto (June 1942-May 1943), encompassing the designation of Theresienstadt as an Altersghetto or 'ghetto for the aged'; (iii) Jüdisches Siedlungsgebiet or 'Jewish settlement area' (May 1943-April 1945); and (iv) Liquidierung or 'liquidation’ (from April 1945). A similar classification, albeit with some differences in timings (most notably, with the phase of the Jüdisches Siedlungsgebiet ending in September 1944) has been proposed by H.G. Adler; see Blodig and White (2012: 180).

In terms of command and control, Theresienstadt was subordinate to the SSoperated Central Office for Jewish Emigration (Prague) which, in turn, reported to SSObersturmbannführer Adolf Eichmann at the Reich Security Main Office (RSHA) in Berlin (United States Holocaust Memorial Museum 2015c). The primary pupose of the camp-ghetto was to concentrate the Jewish population of Prague and all other parts of the Protectorate of Bohemia and Moravia in preparation for deportation to the East. Deportations from the ghetto began in 1942, variously to other ghettos (including Łódź, Riga and Warsaw) or directly to the extermination camps at Sobibór, Majdanek, Treblinka and Auschwitz (Figure 1A). The final liquidation of the ghetto commenced in the autumn of 1944 , with transports to Auschwitz occuring every 1-3 days in late September and early October (Lederer 1953: 232-8). All told, some 140,000 Jews were transported to Theresienstadt during the course of the war, of whom more than 88,000 were subsequently deported and almost 34,000 died in the ghetto in consequence of starvation, disease and other causes. The remainder were resident when the ghetto was finally liberated in the spring of 1945 (Fischel 1998; Hájková 2018; Prochnik 1945; United States Holocaust Memorial Museum 2015c).

Allthough Theresienstadt was - first and foremost - a desperately overcrowded waystation for those destined for the East, Holocaust scholars have placed emphasis 
on the portrayal of Theresienstadt as a 'model camp' by the Nazi propaganda machine (see for example: Farré and Schubert 2009; Margry 1992, 1999; Woolford 2010). A number of prominent members of the intelligentsia were interned there and, as part of a Nazi 'embellishment project', some cultural activities (including live theatre, orchestral and choral concerts and poetry recitals) were tolerated by the captors (Intrator 2004; Karas 1985; Lederer 1953: 125-30; Modlinger 2010; Rovit 2000). The ghetto's physical appearance was also improved at one stage in its existence, all in an attempt to delude the outside world that life there had some sort of approximation to normality. Such was the façade in June 1944 when the German authorities permitted Dr Maurice Rossel, Swiss delegate of the International Committee of the Red Cross (ICRC), to visit the ghetto. As François Bugnion explains of this episode:

In the the weeks preceding Rossel's visit the ghetto had been carefully refurbished and flower beds planted. Everything was done to give the impression that the Jews spent happy and peaceful days under the benevolent gaze of their German protectors, and this was certainly the image it projected, not so much in Dr Rossel's report following the visit, but in the photos and water colour sketches which accompanied it (Bugnion 2003: 239).

In the event, Rossel was unable to talk privately to any of the residents, and the ICRC refused to pass on their report to either the German authorities or the Allies (Bugnion 2003: 239-40).

\section{Data Sources}

Notwithstanding the efforts of the Nazis to sequestrate and destroy records and 
documents relating to Theresienstadt (along with other sites associated with Nazi atrocities) in the latter months of the war, sufficient records were preserved by members of the Jewish Council and other parties and organisations to permit a reconstruction of transports, demography and communicable diseases in the ghetto. Our examination draws on two primary archival sources: (i) the compiled correspondence and statistical records of Theresienstadt held in the Archives du Comité International de la Croix-Rouge (ACICR), Geneva; and (ii) the statistical compilation of demographic, health and disease records prepared by Robert Prochnik under the title Židé v Terezině: Statistické Sestavení (Jews in Theresienstadt: A Statistical Report) and dated July 1945 (Prochnik 1945). We consider each data source in turn.

(i) Archives du Comité International de la Croix-Rouge (ACICR), Geneva. The relevant records are collected in two folders (ACICR G59/12-368, G59/12-369) and comprise delegate reports, official correspondence and notes on activities in connection with ghetto and its liberation. Included in the second folder is a diverse collection of statistical summaries, plans, reports and related materials for the period 1941-45. These documents had been gathered by Paul Dunant, ICRC delegate, around the time that the ghetto had come under the protection of the ICRC in May 1945 (Lederer 1953: 191). Among these latter documents are systematic tabulations of arrivals/departures of transports to/from Theresienstadt in the period November 1941-April 1945. The records run to more than 900 entries over 40 pages and include information on the place of assembly of each transport, the number of males and females by age cohort (0-14 yrs., 15-45 yrs., 46-60 yrs., and 61 yrs. and over) and, where applicable, the official transport identification code. 
(ii) Prochnik's statistical compilation (Židé v Terezíně). Robert Prochnik was an Austrian Jew and close associate of Dr Benjamin Murmelstein (Chief Rabbi of Vienna and, later, Judenältester of Theresienstadt) who was detained at Theresienstadt from October 1942. From September 1943, Prochnik assumed responsibility for the ghetto's transport logistics and was, in practice, the last Jewish official to be seen by many of the ghetto's deportees. In the closing months of the war, when the German authorities attempted to destroy materials that contained the personal records of prisoners, Prochnik and others succeeded in preserving many of the records (Prochnik 1945; Rabinovici 2011). After the liberation of Theresienstadt in May 1945, Prochnik continued to work in the central secretariat of the ghetto, during which time he used the preserved records as the basis for his 38-page statistical compilation Židé v Terezině. The compilation includes, inter alia, tabulations of the ghetto's demographic structure, prisoner arrivals and departures, housing, overcrowding, health conditions and morbidity and mortality. Data are variously presented for daily, monthly, sixmonthly and annual intervals and extend from November 1941 to June 1945.

Given the prominent administrative roles of both Dunant and Prochnik in the weeks and months after the liberation of the ghetto, we can speculate that the lists of transports found in the ICRC records were among the documents that had been preserved by Prochnik. More generally, Prochnik acknowledged that his statistical report was reliant on occasionally fragmentary demographic, health and disease records, although he considered such limitations to be relatively minor in the broad depiction of the demographic and epidemiological history of 140,000 Jews (Prochnik 1945: 2). Indeed, Prochnik's records subsequently assumed considerable importance as official registers and were used, inter alia, in the identification and arrest of SS 
officers and former Theresienstadt guards (Rabinovici 2011: 180).

\section{Transports and Demography}

To deconstruct the geographical patterns and demographic composition of the transports, we draw on the camp records in ACICR (G59/12-369.01, 369.03). The records span a 42-month period, from the arrival of the first transport (originating from Prague and designated Aufbaukommando I or 'AK I' by the German authorities) on Monday, November 24, 1941 to the arrival of the last transport (XXVI/4 from Sered' in the Slovak Republic) on Saturday, April 7, 1945. For each transport, information on the date of arrival/departure, the place of assembly/destination and demographic (gender and age) structure was abstracted to form a geocoded database of transports. This database was supplemented by information from the International Institute for Holocaust Research's Shoah (Holocaust) Deportation Database (International Institute for Holocaust Research 2017) and the statistical compilation of Lederer (1953: 199-262). Consistent with the records of the ACICR, a 'transport' was defined in the database as any discrete and documented arrival or departure of one or more prisoners and for which a transport code was typically allocated (including discharges, escapees, fugitives and transfers involving the state police). So defined, the resulting database included records of 904 transports of widely varying size (1-5,000 people), divisible into 649 transports into the ghetto and 255 out (Table 1).

\section{TABLE 1 NEAR HERE}

\section{Morbidity, Mortality and Communicable Diseases}

The geocoded database of transports was linked to statistical information on causespecific morbidity and mortality in Theresienstadt, 1941-45, assembled by Prochnik 
(1945: 26-37). We supplement this information with case data on a specific epidemic outbreak documented by Vojtěch Adalbert Král (1947) and with contextual information on the general health conditions of the ghetto included in the survivor account of Zdenek Lederer (1953: 135-44, 263-5).

\section{Transports, Demography and Disease}

Before the ghetto was established in late 1941, the resident population of Theresienstadt was 3,700 (Lederer 1953: 2). Once the ghetto was formed, an average of 35,000 people were interned in Theresienstadt at any one time, with the population exceeding 58,000 in September 1942.

\section{The Geography and Demography of Transports}

What were the geographical patterns of the transports which brought the Jews to Theresienstadt? Figure 2 is based on the place of assembly of transports and plots the number and demographic composition of people who were removed to the ghetto, November 1941-April 1945. The map provides a sense of the long geographical reach of the ghetto and the cosmopolitan mix of nationalities, cultures and languages of Jews that came to characterize the ghetto's social space (Lederer 1953: 54-5). The dominance of local transfers from Prague, Brno and other towns and cities in the Protectorate is apparent, as is the large number of transfers from Austria (Vienna) and from all parts of Germany. Elsewhere, the role of Westerbork as a gathering point for Jewish prisoners in Holland is also clear. Underpinning this broad geographical mix, Figure 2 also shows that there was a female bias everywhere; men were needed elsewhere for forced labour and were underrepresented in the transports to Theresienstadt. 


\section{FIGURE 2 NEAR HERE}

Until May 1942, transports to Theresienstadt reflected the initial intention to concentrate the Jewish population of Bohemia and Moravia and, as such, were dominated by Jews of all ages from Prague and other places in the Protectorate (Figures 3 and 4). Beginning in June 1942, however, the demographic structure of Theresienstadt's population began to change (Figure 5). The origins of this transition can be traced to the Wannsee Conference (January 1942) and the pronouncement of SS-Obergruppenführer Reinhard Heydrich that Theresienstadt would be designated as an Altersghetto ('ghetto for the aged') to accommodate older, privileged and famous Jews from Germany and Austria (Woolford 2010). Between June and September 1942, almost 40,000 such individuals - mostly over the age of 60 years - arrived on more than 130 transports from Berlin, Vienna and elsewhere (Figure 3).

\section{FIGURE 3 NEAR HERE}

FIGURE 4 NEAR HERE

FIGURE 5 NEAR HERE

The very high deaths rates that resulted from the gross overcrowding of the elderly arrivals from Germany and Austria, combined with additional arrivals and deportations to the East, resulted in a reshaping of the age-sex pyramid in the latter months of 1942 (Figure 6). Writing of the developments, Zdenek Lederer observes how:

At the end of Setepmber [1942] the number of prisoners over sixty-five years of age had been reduced to 45 per cent of the Ghetto population; further deportations and deaths reduced the figure to 33 percent at the end of December 1942. Thus death, deportations and the arrival of further 
transports augmented the number of young prisoners (from sixteen to forty-five years) from 23 per cent ... at the end of September to 29 per cent at the end of December; the corresponding figures for the age group from forty-five to sixty-five years were 26 per cent at the end of September and 31 per cent at the end of December (Lederer 1953: 51).

\section{FIGURE 6 NEAR HERE}

The appointment of Anton Burger as Commandant of Theresienstadt in the mid-summer of 1943 followed a six-month period when new arrivals were comparably few in number (Figure 3). Burger's appointment effectively marked the onset of Theresienstadt's incarnation as a Jüdisches Siedlungsgebiet or 'Jewish settlement area' (Prochnik 1945: 6) and so began one of the most notorious exercises in Nazi ghetto propaganda. With the implementation of the aforementioned 'embellishment project' (Lederer 1953: 88-121), the deceit of Theresienstadt as a model Jewish settlement was played out on both film and during the aforementioned ICRC visit in June 1944 (Farré and Schubert 2009; Margry 1992, 1999; Woolford 2010). The decision to promote Theresienstadt as a model settlement necessitated a reduction in the visible misery and overcrowding in the ghetto. The matter was managed locally by selective deportations to the East and resulted in the relative demographic balance of the age-sex pyramid for June 1944 (Figure 6) (Lederer 1953: 105-15). Subsequent changes in the ghetto's demographic structure as depicted in Figure 6 were largely associated with the deportation of some 5,000 young males in the early autumn of 1944 (age-sex pyramid for October 1944), ostensibly associated with the concerns of the German authorities over a possible camp revolt (Lederer 1953: 140), and the arrival of prisoners from other camps in the early months of 1945 (age-sex pyramid for April 1945). 
To summarise, while deaths and deportations played a pivotal role in determining the demographic structure of Theresienstadt, so too did the demographic composition of prisoner transports from across Nazi Europe - initially from Bohemia and Moravia and proximal countries (Germany and Austria) and then from further afield (West Prussia, Denmark and the Netherlands) (Figure 3). Within this framework, the national age-sex pyramids in Figure 4 identify two distinct groups: (i) Austria, Germany and West Prussia and Wartheland, where females aged $\geq 61$ years were in the majority; and (ii) Bohemia and Moravia, Denmark and the Netherlands where males and females of reproductive and working age group, 15-45 years, were in the majority.

To explore further the underpinning geography of Figures 3-6, Figure 7 uses techniques of multidimensional scaling (MDS) and cluster analysis to map those locations from which transports mirrored ('similar') or otherwise ('not similar') the overall monthly time series of transportees in two sample demographic groups: females aged $\geq 61$ years (Figure 7A) and males aged 15-45 years (Figure 7B). Analytical details are provided in the Appendix. In brief, the maps in Figure 7 were produced in two steps:

(i) Step 1: multidimensional scaling (MDS) mapping. The concepts that underpin MDS mapping are straightforward (Cliff et al. 1995). On a conventional geographical map, the relative locations of points correspond to their (scaled) geographical locations. In MDS mapping, the relative locations of points correspond instead to their degree of similarity on some variable measured for 
them. ${ }^{3}$ In general terms, points that are similar for the variable measured are positioned close to each other in the MDS space, while points that are dissimilar are widely separated. If the MDS configuration is formed in two dimensions $(m=$ 2 ), the resulting configuration is 'map-like' and the location of each point is conventionally specified by $x y$ co-ordinates. As described in the Appendix, twodimensional MDS mapping was used in the present analysis to measure the degree of similarity of transport assembly points in terms of the demographic composition (females aged $\geq 61$ years; and males aged 15-45 years) of the associated transports to Theresienstadt. As similarity was measured in terms of the time-series structure of each demographic group (Appendix), it provides a measure of the synchrony of assembly points in the movement of members of that group. Assembly points for which transports had similar demographic structures in time (that is, synchronous) were positioned close to each other in the resulting two-dimensional space, while assembly points for which the transports had dissimilar demographic structures in time (that is, non-synchronous) were distant from each other in the space.

(ii) Step 2: cluster analysis. As an analytical basis for discriminating between 'similar' (synchronous) and 'not similar' (non-synchronous) transport assembly

${ }^{3}$ The MDS problem is to find a configuration of $n$ points in $m$-dimensional space such that the inter-point distances in the configuration match the experimental (dis)similarities of the $n$ objects as accurately as possible. Accuracy is determined from the stress coefficient, where stress is defined as the residual sum of squares of modelled and experimental inter-point distances. Low values of the stress coefficient imply a good fit of the model while high values of the stress coefficient imply a poor fit. See Cliff et al. (1995) for further details. 
points in Step 1, the $x y$ co-ordinates of points in the two-dimensional MDS spaces were then subjected to a hierarchical (complete linkage) cluster analysis. The principles of cluster analysis are summarised by Everitt et al. (2011). At the beginning of the clustering process, each element (here, each transport assembly point) is in a cluster of its own. The clusters are then successively combined into larger clusters in such a way that intra-group similarities in the elements are greater than inter-group similarities. For the purposes of the present analysis, the position of the maximum separation between clusters was then taken as a basis for determining similar (synchronous) and not similar (non-synchronous) assembly points in terms of the demographic composition of transports.

\section{FIGURE 7 NEAR HERE}

On this basis, the maps in Figure 7 identify those parts of the Reich that were similar/synchronous (black circles) or not similar/non-synchronous (white circles) in terms of the transportation of older females (Figure 7A) and younger males (Figure 7B) to Theresienstadt. For older females, the many black circles in Figure 7A are consistent with the early designation of Theresienstadt as an Altersghetto and point to a broad geographical synchrony of transports from many parts of the Reich in this phase of the ghetto's existence. In comparison, the map for younger males in Figure 7B shows a less geographically coherent pattern. In addition to Bohemia and Moravia, particular foci of synchronous activity are evident in western Germany and neighbouring areas of Holland and Denmark. Many of the transports from the latter two countries arrived at Theresienstadt between November 1943 and April 1944 and the associated representations of the Danish Red Cross and the ICRC to visit the 
ghetto were to provide an important impetus to the implementation of the ghetto's 'embellishment project' (see, for example, Lederer 1953: 100).

\section{Transports and Communicable Diseases in Theresienstadt}

When combined with insanitary and overcrowded conditions, the near-continuous arrival of transports from all parts of the Reich had a deleterious impact on health conditions in Theresienstadt (Brush 2004; Hájková 2018; Hoenig et al. 2004; Lederer 1953: 135-44). Not least, the population flux added to the overcrowding and served in the frequent introduction of all manner of communicable conditions that spread in epidemic form through the ghetto (Král 1947; Lederer 1953: 135-44). In the words of Hoenig and colleagues:

From a medical perspective, Ghetto Terezín [Theresienstadt] was a disaster. The ghetto quickly became overcrowded with Jews, resulting in epidemics of typhoid fever, scarlet fever, typhus and tuberculosis. Pneumonia, gastroenteritis and cardiovascular diseases claimed many thousands of lives. Food was in short supply and as a consequence malnutrition was common among the ghetto population, often contributing to the high death rate among the ghetto Jews. The first doctors in Ghetto Terezín had no medical equipment or supplies; thus, people with surgical problems such as appendicitis would die because of lack of treatment (Hoenig et al. 2004: 131).

Some impression of the gross levels of overcrowding can be gained from Table 2. For December 1941, Prochnik (1945) estimated the population density of the ghetto at 181,500 persons per $\mathrm{km}^{2}$ of living space. With the subsequent arrival of transports 
(Figure 3), the population density grew to a peak of 321,000 persons per $\mathrm{km}^{2}$ in July 1942 - well over 50 times the density of contemporary Prague. Thereafter, with deportations and efforts to create additional living space, Table 2 shows that levels of overcrowding reduced progressively to a low of 33,200 persons per $\mathrm{km}^{2}$ in January 1945 (Prochnik 1945; see also Lederer 1953: 35-56).

\section{TABLE 2 NEAR HERE}

Notwithstanding the overcrowded and insanitary conditions, a well-organized Health Department was established by the self-governing Jewish Council. Among the prisoners, doctors and nurses established hospitals and clinics to treat the sick, while lessons in public health and hygiene were provided to the community (Goldman 1994; Hájková 2018; Hoenig et al. 2004; Horáčková et al. 2017). Various measures were implemented to control epidemics, including delousing, the isolation of people with communicable diseases, and measures to promote sanitation and hygiene. To an extent, the SS supported such activities with a view to limiting the risk of disease transmission to the local German population (Hájková 2018). Figure 1C shows, inter alia, the location of the Jewish Council, the main hospital and the delousing station. In association with these efforts, the average monthly death rate per 1,000 population fell progressively from 30.6 (1942) to 24.2 (1943) and 12.6 (1944) (Prochnik 1945). Nevertheless, more than 33,000 prisoners died as a consequence of disease, starvation, suicide, execution and other causes in the ghetto, with enteritis alone claiming some 8,600 lives in the period 1942-44 (Prochnik 1945).

Documented patterns of mortality in Theresienstadt are summarized in Figure 8. As Figure 8A shows, mortality spiked at 3,941 recorded deaths in September 1942. This coincided with the time when the ghetto's population was at a maximum (Figure 
8A), levels of overcrowding had reached their peak (Table 2) and the proportion of older prisoners ( $\geq 61$ years) among the arrivals was high (Figure 5). Thereafter, mortality fell away with the declining population and population density to $<1,000$ deaths per month from May 1943 and <500 deaths per month from June 1944. Infectious diseases (18,207 deaths) and malnutrition (6,534 deaths) were the most commonly recorded causes of mortality (Figure 8B). Some two-thirds of these deaths occurred among females, with gastroenteritis, pneumonia and other infectious diseases of the respiratory system (including pulmonary tuberculosis) accounting for approximately 50 percent of the documented mortality in both genders (Lederer 1953: 264-5; Prochnik 1945).

\section{FIGURE 8 NEAR HERE}

The epidemiological record of Theresienstadt began with scarlet fever in the winter of 1941-42 and ended with typhus fever in the late spring and early summer of 1945 (Hájková 2018; Lederer 1953: 135-44). Figure 9 summarizes this epidemic history (Figure 9B) in relation to the arrival of transports at the ghetto (Figure 9A). Consistent with the view that "most of the contagious diseases were brought into the Ghetto by new transports" (Lederer 1953: 138), the graphs show a clear visual correspondence between the onset of epidemics and the major spikes of arrivals in: (i) the summer of 1942 (conjunctivitis, enteritis, jaundice, pediculosis, pulmonary tuberculosis and typhoid); (ii) the winter of 1942-43 (diarrhoea and diphtheria); and (iii) the summer of 1943 (encephalitis and poliomyelitis). In terms of recorded morbidity, communicable diseases were particularly prominent in the main arrival period of 1942-43 (Figure 10); this was also the period of greatest mortality in the period prior to the ghetto's liberation in May 1945 (Figure 8B). 


\section{FIGURE 9 NEAR HERE}

FIGURE 10 NEAR HERE

The inferred links between the arrival of transports and the timing of epidemics are corroborated by the survivor account of Zdenek Lederer. Pediculosis (louse infestation), with the attendant risk of typhus fever and other louse-borne diseases, was one of the first communicable conditions to reach epidemic proportions in the ghetto (Figure 9B). The infestation was introduced "when several thousands of lice-infected prisoners from Vienna" arrived in the summer of 1942 (Lederer 1953: 142). This influx of new arrivals - some 6,000 in a series of six transports (IV/1-IV/6) from Austria between June 21 and July 29 (ACICR G59/12-369.01, 369.03) - overran the operational capacity of the delousing station and the infestation spread to others in the ghetto (Lederer 1953: 142).

Mysterious contagions also gained entry via Theresienstadt's Schleuse. A virulent outbreak of an unidentified form of encephalitis in the autumn and winter of 1943 was described in particular detail by the prisoner-doctor, Vojtěch Adalbert Král (Král 1947; Rollin 1988) (Figure 9B). ${ }^{4}$ The source of the outbreak is unknown,

4 The exact nature of the encephalitis observed by Král is unclear. The disease was characterized by the gradual or abrupt onset of symptoms that were indicative of central nervous system involvement (headache; dizziness; uncertain gait; fatigue; somnolence; impaired memory; and visual disturbances). The symptoms persisted for 1-4 weeks and the case-fatality rate was low $(<1$ percent). The clinical picture was similar to polioencephalitis or encephalomyelitis of a type that was related in its symptomology to encephalitis lethargica (von Economo's disease). Unfortunately, 
although Král observes that the main epidemic was preceded by sporadic cases in the summer months to August. These early cases corresponded with the arrival of almost 4,000 people on a series of transports, primarily from Prague (2,154 persons), Berlin (798 persons), Hamburg (189 persons), Breslau (179 persons) and Vienna (169 persons) amongst other locations (ACICR G59/12-369.01, 369.03) (Figure 9A). From a possible introduction with one or more of these transports, the disease acquired epidemic proportions in the winter of 1943-44 and continued to circulate at a lower level until the ghetto was liberated in the spring of 1945 (Figure 11A). Demographically, the disease was highly selective. Over 75 percent of the 978 recorded cases were female, with a marked predeliction for those aged 11-20 years; only eight cases were recorded in children aged 10 years or less (Figure 11B).

\section{FIGURE 11 NEAR HERE}

At the beginning of 1944, while the epidemic of encephalitis was still prevalent, another new outbreak of an infectious disease (diphtheria) was attributed to the transports that arrived from Holland, West Prussia and from many parts of Germany (ACICR G59/12-369.01, 369.03; Lederer 1953: 142). But, with the Allies advancing in the east and west, it was the spring of 1945 and the arrival of thousands of prisoners who had been hastily evacuated from other camps - variously by train or on foot as survivors of the death marches - which presented one of the gravest communicable disease challenges to the ghetto's Health Department. The first column of 2,000 reached Theresienstadt on April 20, and another 9,000 followed two days later (Lederer 1953: 185-6). Not only did a considerable proportion of the arrivals

however, the German authorities forbade any effort to identify the aetiology of the disease and the cause of the outbreak remains unknown (Král 1947). 
present with active pulmonary tuberculosis; they also overwhelmed the capacity of the delousing stations and carried typhus fever into Theresienstadt (Figure 9B). From the first documented case of typhus fever on April 24, Figure 12A shows that epidemic mortality grew to a peak in the latter half of May when some 20-30 deaths per day were attributed to the disease. The epidemic eventually terminated at the end of June, by which time a documented 2,190 typhus patients had been admitted to hospital and over 500 patients had succumbed (Prochnik 1945). ${ }^{5}$ While efforts to contain typhus fever served to interrupt the post-liberation repatriation process, Theresienstadt was finally emptied on August 17, 1945 (Lederer 1953: 196-7).

\section{FIGURE 12 NEAR HERE}

\section{The Geographies of Deportation and Liquidation}

Figure 13 maps the geography of deportations from Theresienstadt. As the graph shows, mass deportations began in January 1942, initially to Riga, Lublin and other ghettos and camps in the north and east and then, from May, directly to the extermination camps at Sobibór, Maly Trostinec and Treblinka. The first transport for Auschwitz ('Transport By') left on Monday, October 26, with 1,866 people and, from thereon, Auschwitz became the principal destination for deportees. Some 46,000 residents of Theresienstadt were deported to that place in the 24 months to October 1944, with major spikes of deportations in early and late 1943 and, as the systematic

${ }^{5}$ It is likely that these figures underestimate the true extent of the morbidity and mortality from typhus fever. According to Hájková (2018), for example, the number of deaths associated with the epidemic exceeded 1,200, with the majority of the deaths occurring among those who had recently arrived from other camps. 
liquidation of the ghetto began, in the autumn of 1944 (ACICR G59/12-369.01, 369.03) (Figure 13).

\section{FIGURE 13 NEAR HERE}

Specific information on the disease status of the deportees is virtually nonexistant, although it is reasonable to assume that communicable conditions exited the ghetto in the same way that they had entered; through the Schleuse. In some instances, sickness and disease is reputed to have protected the sufferers from deportation and, on occasion, those with specialist knowledge of such conditions - including Adalbert Král - may also have been spared (Lederer 1953: 25; Rollin 1988). But this was not always the case. In the summer of 1944, for example, the decision was taken to deport all patients in the hospital's tuberculosis ward (Lederer 1953: 25). Indeed, the use of mass murder as a means of infection control was a familiar concept to the Nazis; as Guenter Lewy observes, a similar fate had befallen the residents of the gypsy quarter of Łódź ghetto in consequence of a typhus fever epidemic in the winter of 1941-42 (Lewy 1999). See, also, Browning $(1988,1995)$.

\section{Conclusion}

The complex relationship between ghettos, health policy and mass murder has featured prominently in historiographical accounts of ghettoization in the Holocaust; see, for example, Cole (2004) and Browning (2005). Drawing on the example of the Warsaw Ghetto, for example, Browning $(1988,1995)$ suggests that health policy was central to the medical rationalisation of both ghettoization and the Final Solution. The advocacy of German doctors for ghettoization rested with the prevailing medical view that Jews were natural carriers of louse-borne typhus fever and needed to be segregated for the protection of the rest of the population. When living conditions in the ghettos of 
Warsaw and elsewhere in Poland resulted in large-scale epidemics of typhus fever in 1940-41, the same doctors were receptive to the implementation of mass murder as a means of disease control (Browning 1988, 1995). Whilst the Warsaw Ghetto is just one example, and the initial impetus for the creation of ghettos undoubtedly varied in time and space (Browning 2005), it is true to say that the ghetto system in Eastern Europe was brutally effective in its promotion of the geographical spread of communicable diseases (Beinfeld 1998; Longacre et al. 2015; Shasha 2002; Weindling 2000). The massing of people in overcrowded and insanitary tenements, barracks and other buildings provided ideal conditions for the high-level transmission of all manner of infections. In instances such as Theresienstadt, the prisoners were drawn from a variety of epidemiological environments, and their resistance to infection was often compromised by mental and physical stress, trauma, extreme nutritional deprivation and the deleterious consequences of rapid exposure to multiple disease agents. The lack of medicines, facilities and equipment, the frequent failure of the captors to assist in the implementation of humane measures of infection control, and the collapse of the conventional rules of social behaviour further compounded the epidemiological dangers of the ghettos (Smallman-Raynor and Cliff 2004, 2018). Indeed, it is hard to imagine a system of mass population dislocation and confinement that was more calculated to degrade human health than the Nazi ghetto system of World War II (Longacre et al. 2015).

As we have already noted, Theresienstadt 'camp-ghetto' was a hybrid space part reception and transit camp and part ghetto - that distinguished it from many of the other ghettos of German-occupied Eastern Europe (Megargee and Dean 2012). Within the context of this hybrid space, we have used methods of map-based visualisation and spatial analysis to aid a geographical understanding of the demographic and 
epidemiological history of Theresienstadt. We have shown that the 'biological space' of the ghetto was the product of complex patterns of prisoner arrivals and departures that, in turn, fed into the successive depictions of Theresienstadt as an Altersghetto and a Jüdisches Siedlungsgebiet. Large numbers of prisoners from across the Reich brought with them the agents of familiar and not-so-familiar diseases, resulting in the frequent epidemiological bombardment of the ghetto's population. Echoing recent scholarship on public health as a form of Jewish political resistance (Beinfeld 1998; Longacre et al. 2015; Shasha 2002; Weisz et al. 2012), the self-governing Jewish Council of Theresienstadt maintained a Health Department that implemented a range of initiatives for the prevention and control of communicable diseases, including health education, patient isolation and prophylaxis against various diseases (Goldman 1994; Hoenig et al. 2004; Lederer 1953: 135-44). Whilst these activities did limit the opportunities for what Lederer calls "disastrous epidemics", it remains the case that an average of some 800 people per month died in the ghetto and that over 20 percent of those who entered Theresienstadt succumbed to starvation, communicable diseases and other causes before they could be deported to the East (Lederer 1953: 135; Prochnik 1945).

The public health impacts of genocidal violence are extreme and demand the close attention of health professionals, planners and policy makers in the twenty-first century (Adler et al. 2004; Fein 1997; Krug et al. 2002; Willis and Levy 2000). These health impacts assume special prominence when, as in the Holocaust, famine and communicable diseases are deemed to be legitimate weapons in the persecution of peoples and races (Rummel 1992: 38-9). Framed by the issues of scarcity, crisis and public health disaster, Longacre and colleagues have drawn an analogy between the ghettos of World War II and the extreme health plight of some refugees and other 
forcibly displaced populations in recent times (Longacre et al. 2015). The death of some 50,000 refugees from cholera and other diarrhoeal diseases in the Goma area of Zaire in the aftermath of the Rwandan Genocide (1994) is illustrative (The Goma Epidemiology Group 1995), and underscores the nexus of genocide, forced population displacement and communicable diseases that we have demonstrated for Theresienstadt and which has profound implications for displaced populations today (Smallman-Raynor and Cliff 2018: 242-69). 


\section{Appendix}

This appendix summarizes the operational details of the MDS and cluster analysis that were used in the formation of Figure 7. The analysis was performed in two steps:

(1) Step 1: $M D S$. For each of two sample age groups (females aged $\geq 61$ years; and males aged 15-45 years), the Pearson correlation coefficient $r$ was computed between the monthly time series of (i) transportees from each of 121 European towns, cities and other assembly locations and (ii) the total number of transportees (irrespective of place of assembly) in the same age-sex category that arrived at Theresienstadt. All time series were formed over a 42-month period, November 1941-April 1945. The resulting correlation matrices were then analyzed using two-dimensional MDS to yield 'maps' of similarities of locations for each of the sample demographic groups. Locations whose time series echoed that of Theresienstadt were positioned close to each other on the MDS maps. Conversely, locations with very dissimilar time series behaviour to Theresienstadt were widely spaced. The fitting procedure yielded stress measures of $0.29\left(R^{2}=0.56\right)$ for females aged $\geq 61$ years and $0.30\left(R^{2}=0.48\right)$ for males aged $15-45$ years.

(2) Step 2: Cluster Analysis. For each demographic group, the xy co-ordinates of locations in the two-dimensional MDS spaces were then subjected to a hierarchical (complete linkage) cluster analysis that yielded the dendrograms in Figure A1. These provided a basis for discriminating between 'similar' (= synchronous) and 'not similar' (non-synchronous) locations as plotted in Figure 7.

\section{FIGURE A1 NEAR HERE}


Table 1. Summary details of transports to and from Theresienstadt, November 24, 1941 to April 7, 1945.

\begin{tabular}{|c|c|c|c|c|}
\hline \multirow[b]{2}{*}{$\begin{array}{l}\text { Size of transport } \\
\text { (people) }\end{array}$} & \multicolumn{2}{|c|}{ Arrivals } & \multicolumn{2}{|c|}{ Departures $^{1}$} \\
\hline & $\begin{array}{l}\text { No. of } \\
\text { transports }\end{array}$ & $\begin{array}{c}\text { Total } \\
\text { people }\end{array}$ & $\begin{array}{l}\text { No. of } \\
\text { transports }\end{array}$ & Total people \\
\hline $1-10$ & 217 & 628 & 152 & 293 \\
\hline $11-100$ & 278 & 16,585 & 40 & 1,482 \\
\hline $101-1,000$ & 135 & 99,325 & 31 & 28,481 \\
\hline $1,001-5,000$ & 19 & 23,162 & 32 & 61,984 \\
\hline Total & 649 & 139,700 & 255 & 92,240 \\
\hline
\end{tabular}

${ }^{1}$ The enumerated departures include a small number of escapees (38 persons involved in 29 recorded episodes). 
Table 2. Population and population density of Theresienstadt at sample points in time.

\begin{tabular}{lcc}
\hline Date & $\begin{array}{c}\text { Number of } \\
\text { persons }\end{array}$ & $\begin{array}{c}\text { Population } \\
\text { density per } \\
\mathrm{km}^{2}\end{array}$ \\
\hline Dec. 1941 & 1,342 & 181,500 \\
Jan. 1942 & 7,350 & 285,000 \\
Jul. 1942 & 21,296 & 321,000 \\
Jan. 1943 & 49,296 & 128,000 \\
Jul. 1943 & 44,621 & 118,000 \\
Jan. 1944 & 34,655 & 103,000 \\
Jul. 1944 & 27,702 & 79,400 \\
Jan. 1945 & 11,568 & 33,200 \\
\hline
\end{tabular}

Source: Data from Prochnik (1945: 27). 

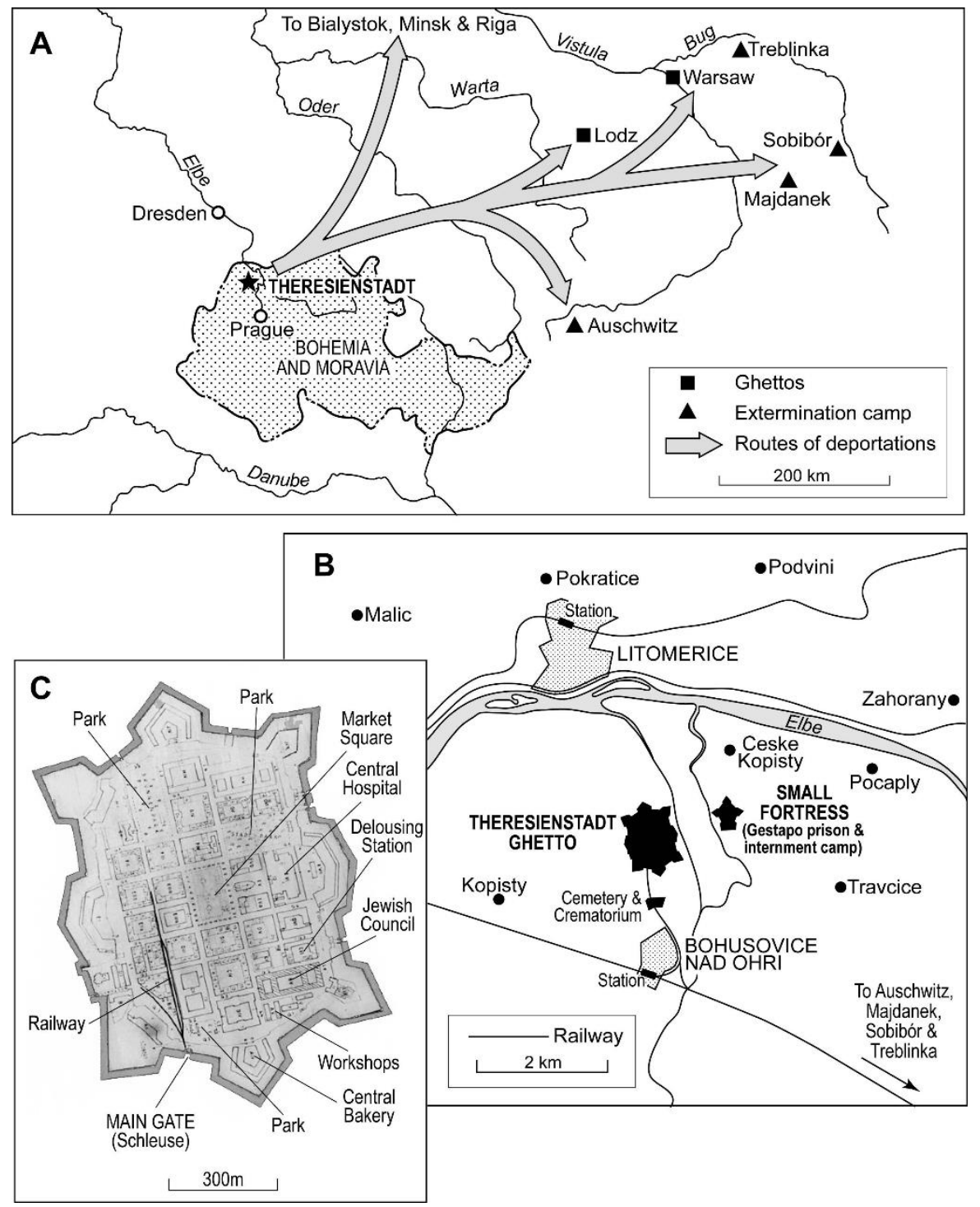

Figure 1. Theresienstadt camp-ghetto. (A) Location of Theresienstadt, situated some $65 \mathrm{~km}$ to the north of Prague. The principal routes of deportations to other ghettos (including Riga, Warsaw, and Łódź) and extermination camps (including Auschwitz) in the period 1942-44 are indicated. (B) Theresienstadt ghetto and environs, 1944. (C) Annotated plan of Theresienstadt ghetto, summer 1944. Sources: (A) redrawn from United States Holocaust Memorial Museum (2015c); (B) redrawn from United States Holocaust Memorial Museum (2015b); and (C) reproduced from United States Holocaust Memorial Museum (2015c), courtesy of Henry Kahn. 


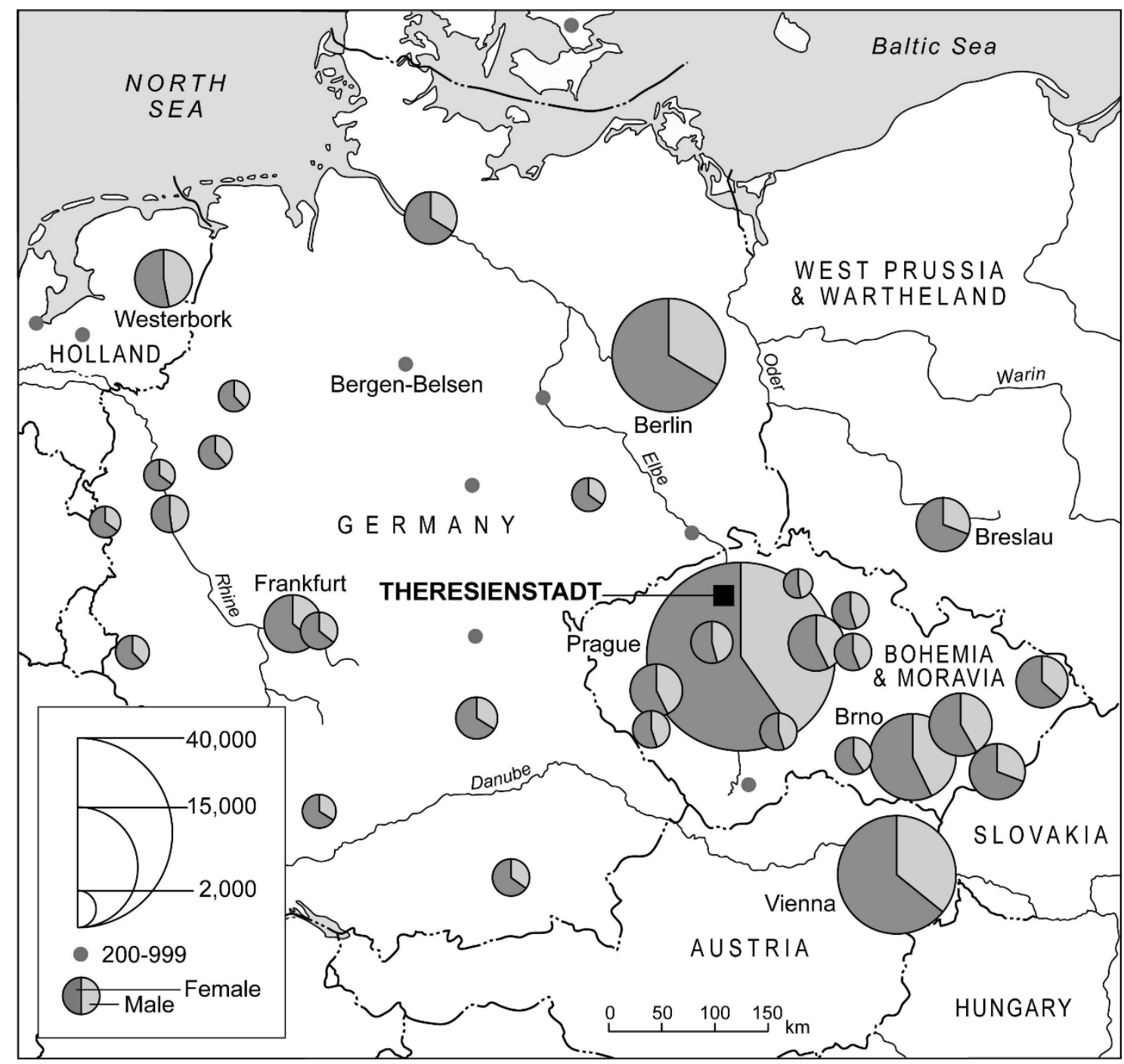

Figure 2. Number of prisoners transported to Theresienstadt, November 1941-April 1945. The divided proportional circles give, by gender, the numbers transported from each assembly point in Nazi-controlled Europe. Note that assembly points involving $<200$ prisoners are not shown. Source: based on data from Archives du Comité International de la Croix-Rouge (ACICR G59/12-369.01, 369.03). 


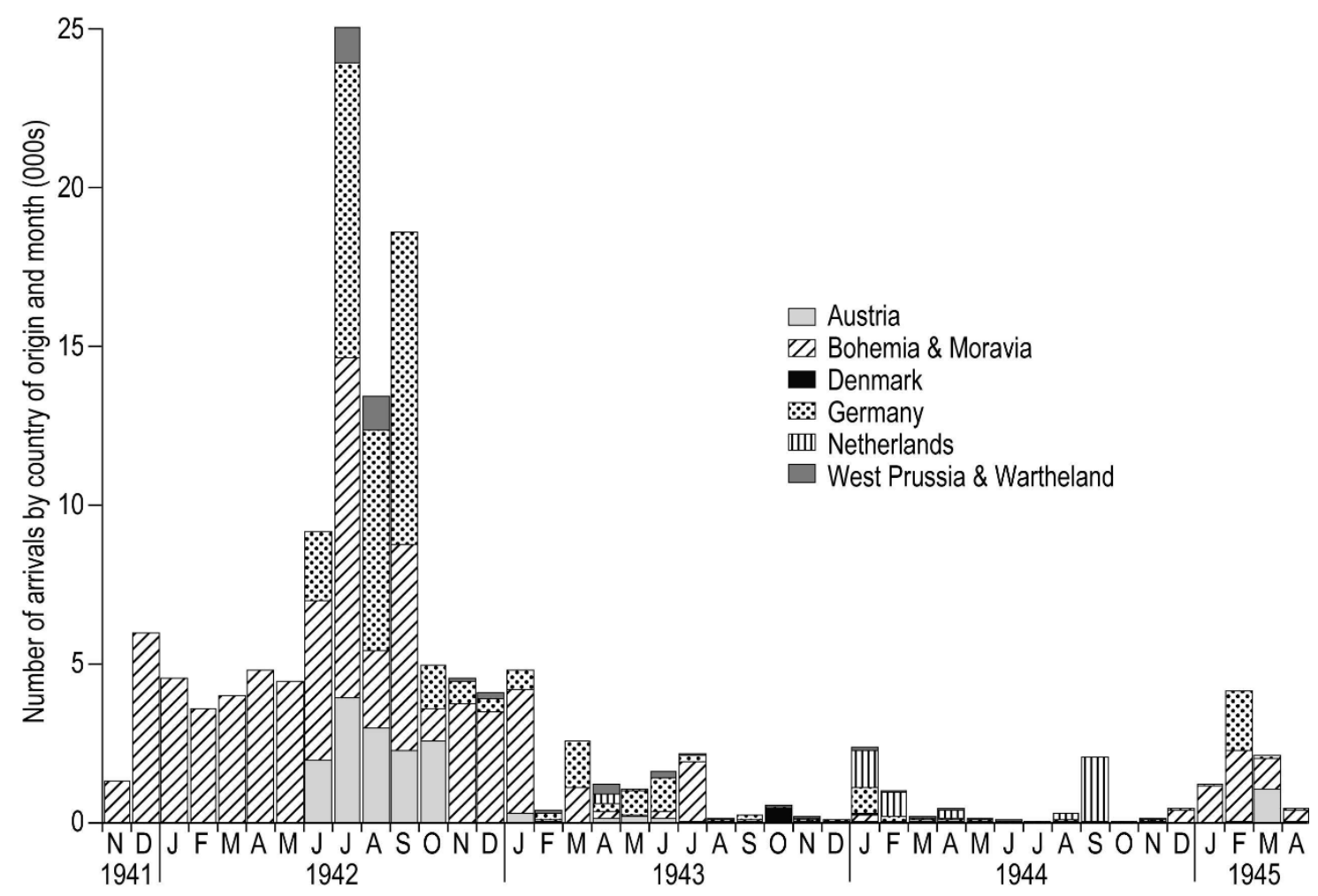

Figure 3. Monthly time series of arrivals at Theresienstadt by country of origin of transports, November 1941-April 1945. Source: based on data from Archives du Comité International de la Croix-Rouge (ACICR G59/12-369.01, 369.03). 

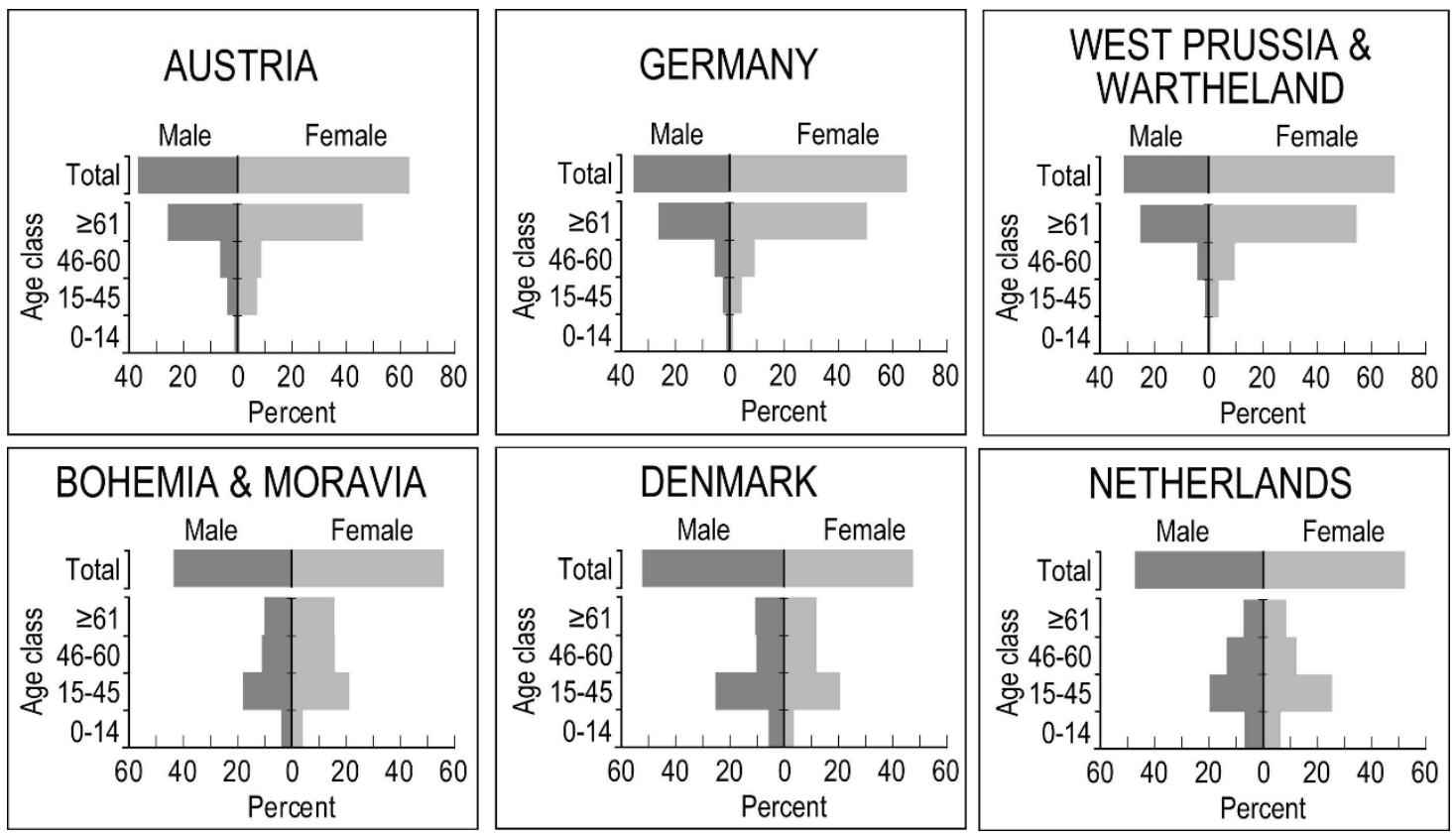

Figure 4. Age-sex structure of arrivals at Theresienstadt from six European countries, November 1941-April 1945. Source: based on data from Archives du Comité International de la Croix-Rouge (ACICR G59/12-369.01, 369.03). 


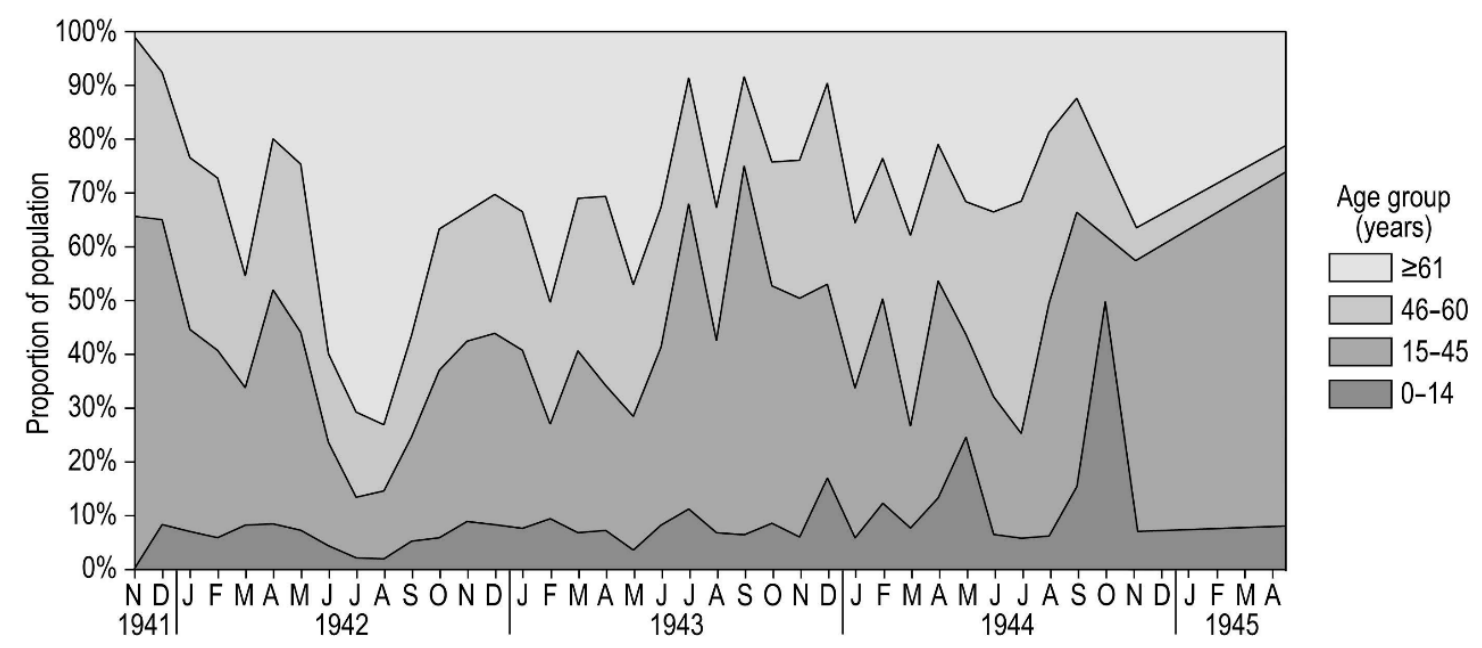

Figure 5. Time series of prisoner arrivals at Theresienstadt, November 1941-April 1945. The stacked line graph plots the percentage of arrivals by age cohort. Source: based on data from Archives du Comité International de la Croix-Rouge (ACICR G59/12-369.01, 369.03) and Lederer (1953: 263). 

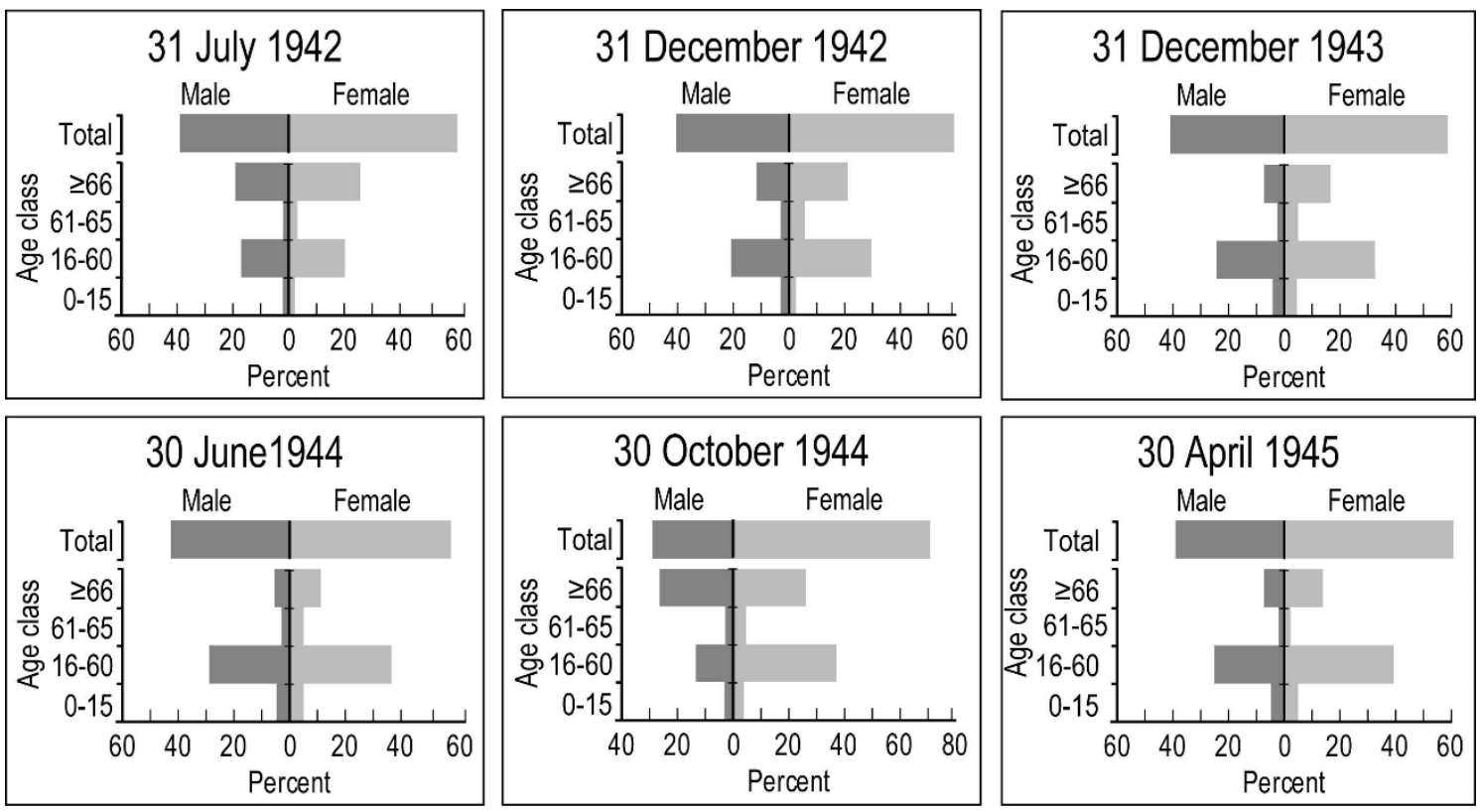

Figure 6. Age-sex structure of Theresientadt's population at sample points in time. The selection of sample points has been determined by data availability. Source: based on data from Prochnik (1945: 22) and Lederer (1953: 263). 

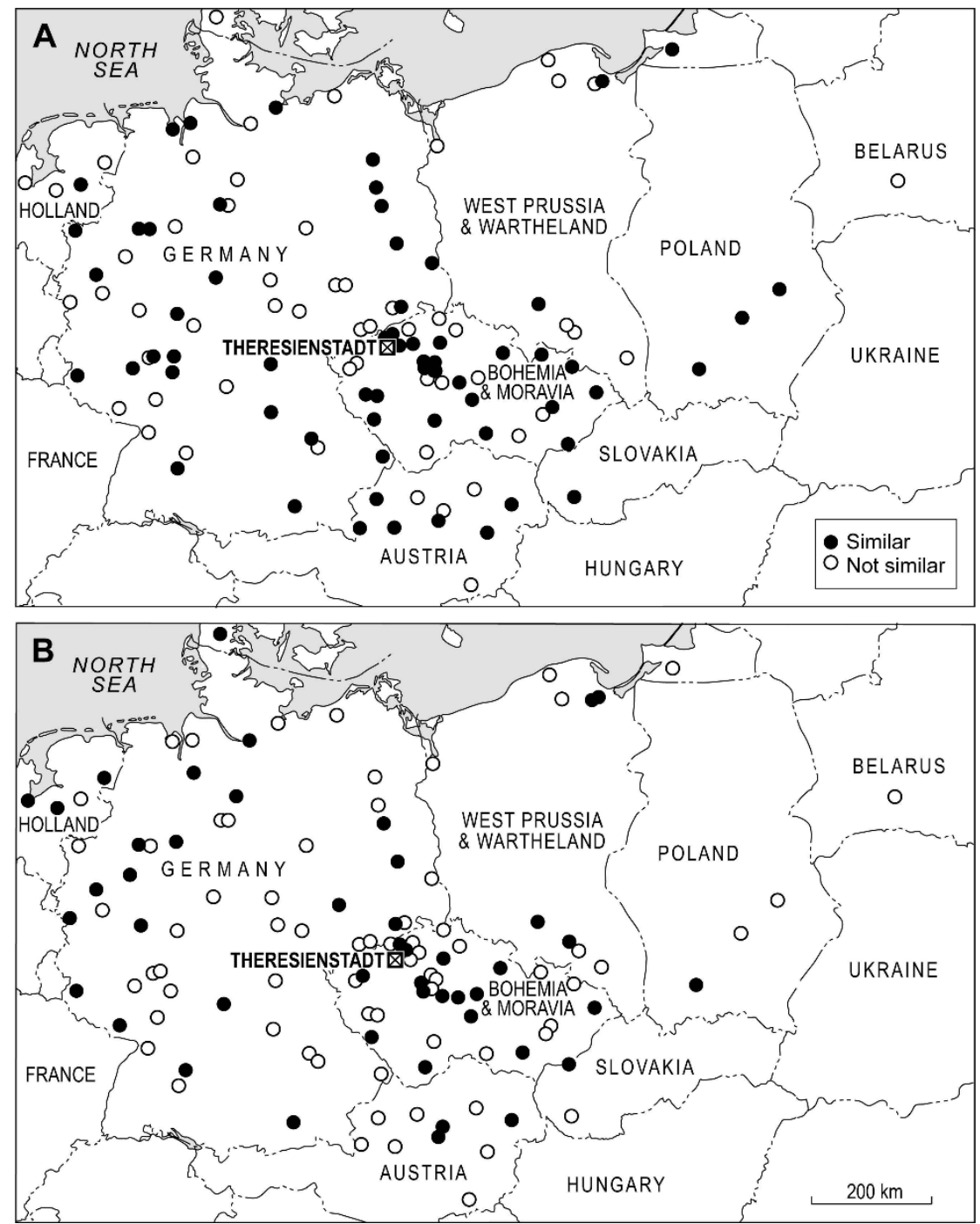

Figure 7. Transports and the demographic structure of Theresienstadt, November 1941-April 1945. The maps are based on techniques of MDS mapping and cluster analysis and show the similarity between the monthly time series of (i) prisoner arrivals from individual assembly locations and (ii) all prisoner arrivals at Theresienstadt, irrespective of the place of assembly. Assembly locations are represented by circles that are coded according to a binary classification of 'similar' (= synchronous; black circles) or 'not similar' (= non-synchronous; white circles) to all arrivals at the ghetto. (A) Females aged $\geq 61$ years. (B) Males aged 15-45 years. Source: based on data from Archives du Comité International de la Croix-Rouge (ACICR G59/12-369.01, 369.03). 

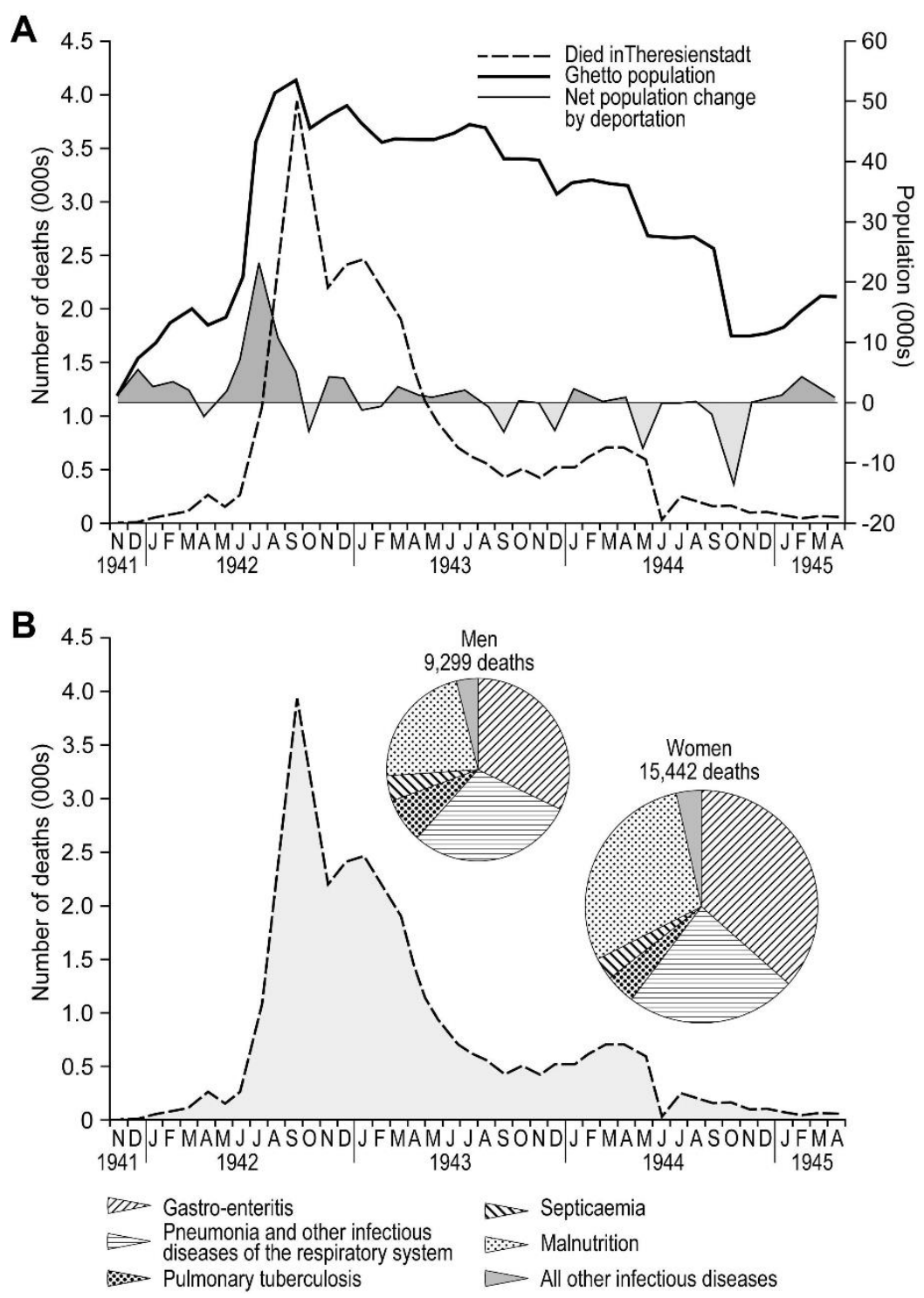

Figure 8. Mortality in the Theresienstadt ghetto, November 1941-April 1945. (A) The heavy line trace tracks the total population of the ghetto on a monthly basis. The shaded line trace shows net population change produced by the prisoner flux. (B) The divided proportional circles show deaths by cause and gender for malnutrition and various communicable conditions; the mortality curve is replotted from graph (A). Source: based on data from Lederer (1953: 247-8, 264-5). 

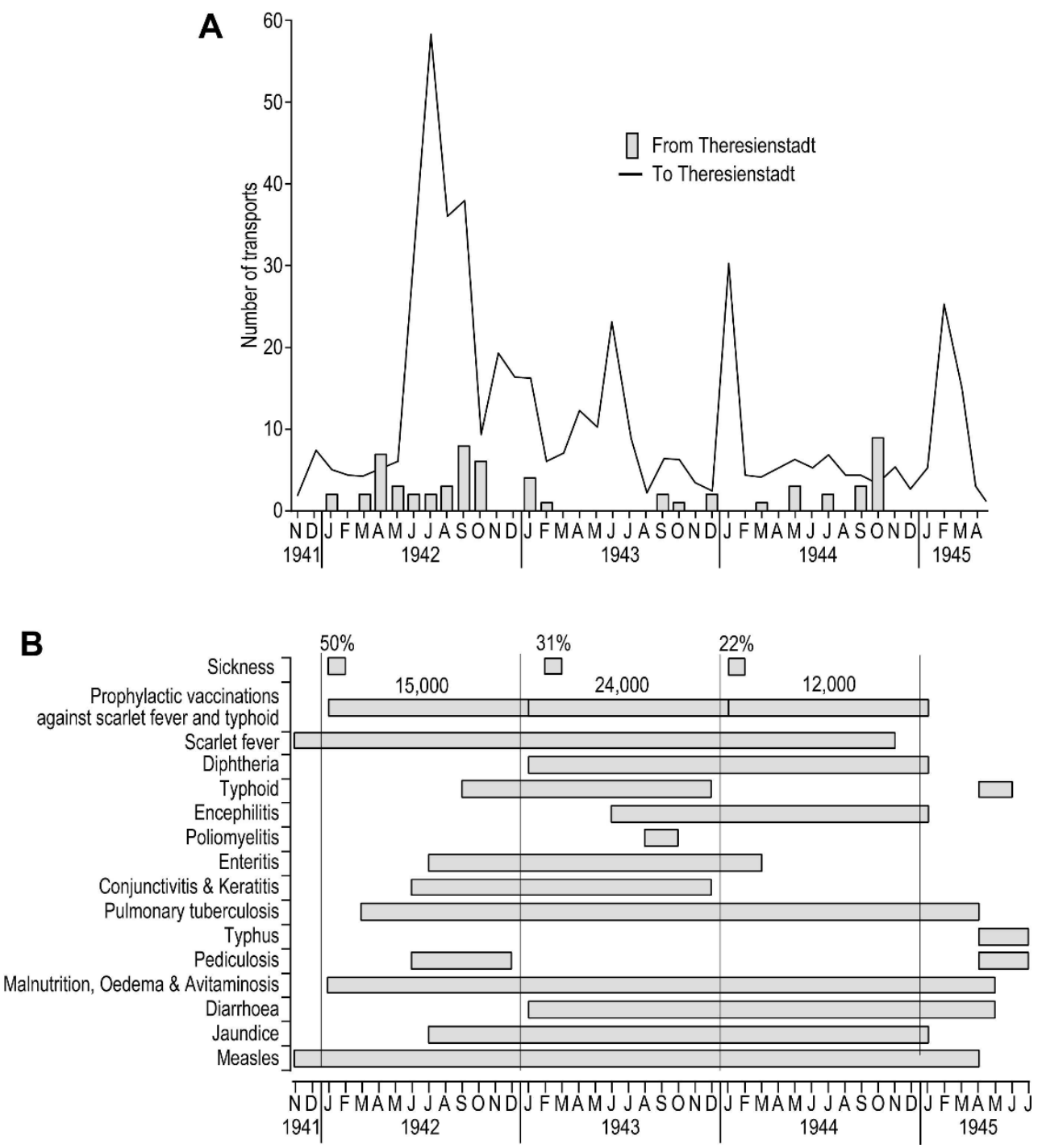

Figure 9. The epidemic history of Theresienstadt, 1941-45. (A) Monthly time series of the number of transports arriving at (line trace) and departing from (bar chart) Theresienstadt. (B) Overview of the main epidemic periods, the diseases involved, and the prophylactic history of the ghetto. Source: based on data from Prochnik (1945) and Lederer (1953). 
A

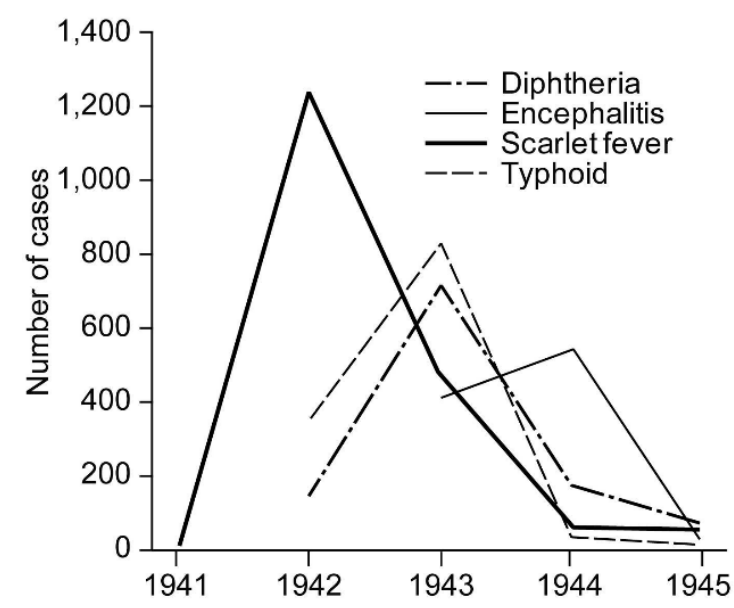

B

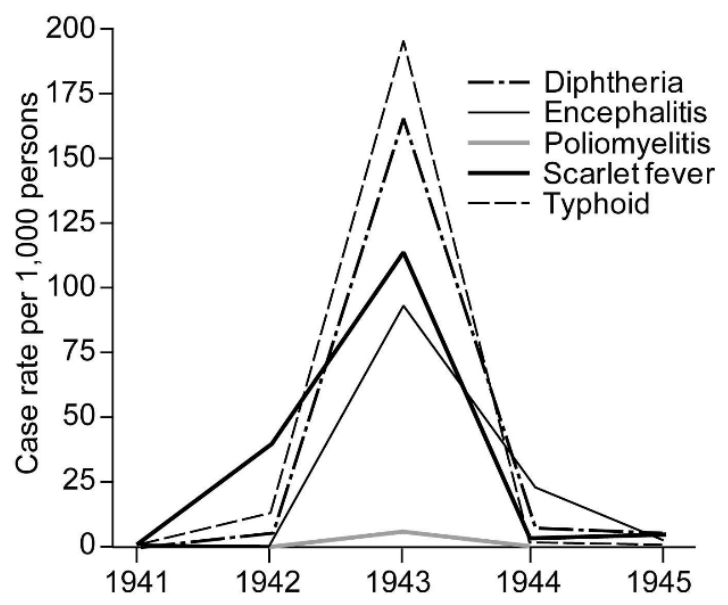

Figure 10. For the most frequently occurring communicable diseases at Theresienstadt, graph A plots the annual count of recorded cases while graph B plots the annual case rate per 1,000 persons. Source: based on data from Prochnik (1945) and Lederer (1953). 

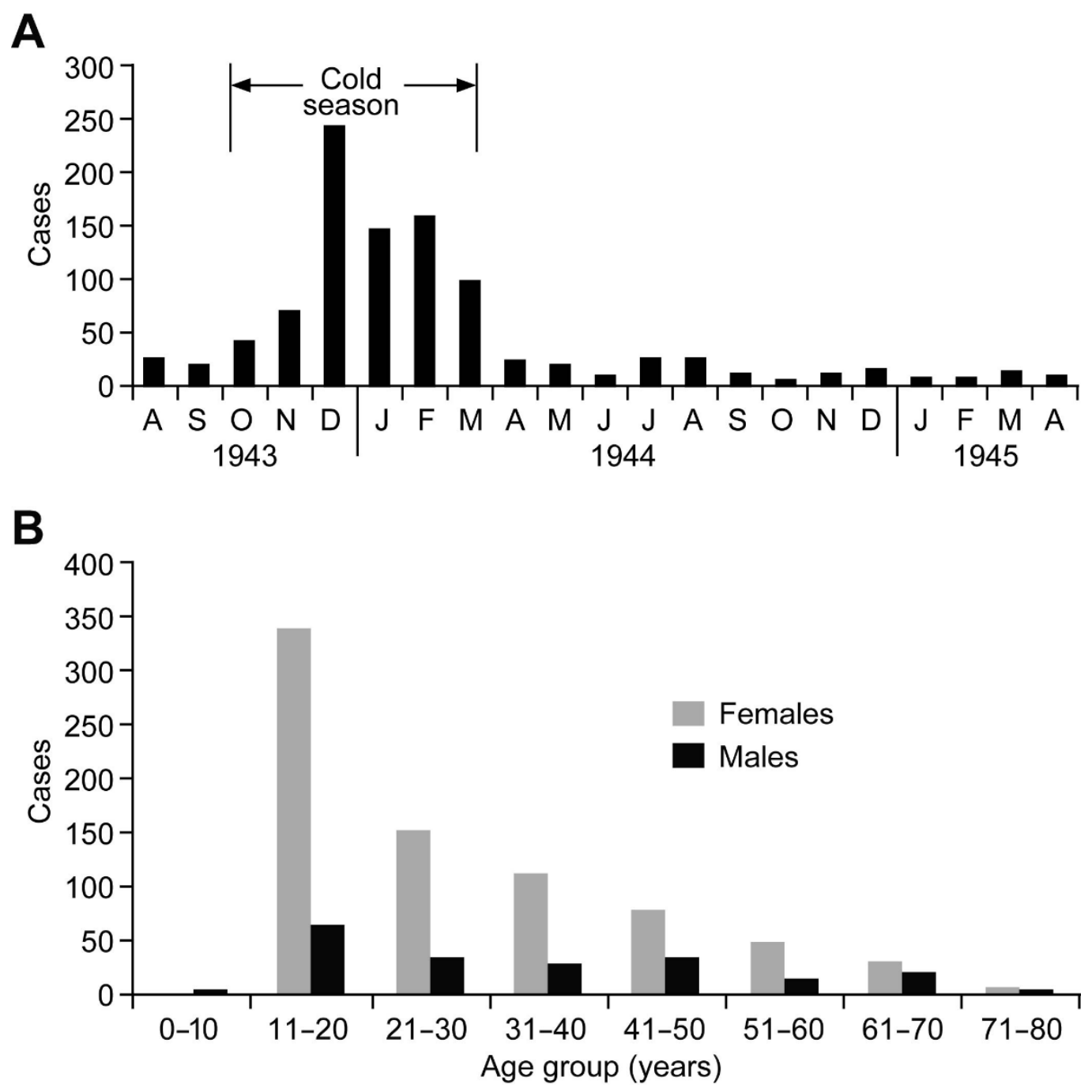

Figure 11. Outbreak of encephalitis in Theresienstadt, summer 1943-spring 1945. (A) Cases by month. (B) Cases by age group and gender. Source: based on data from Král (1947: 404). 


\section{A Typhus fever}

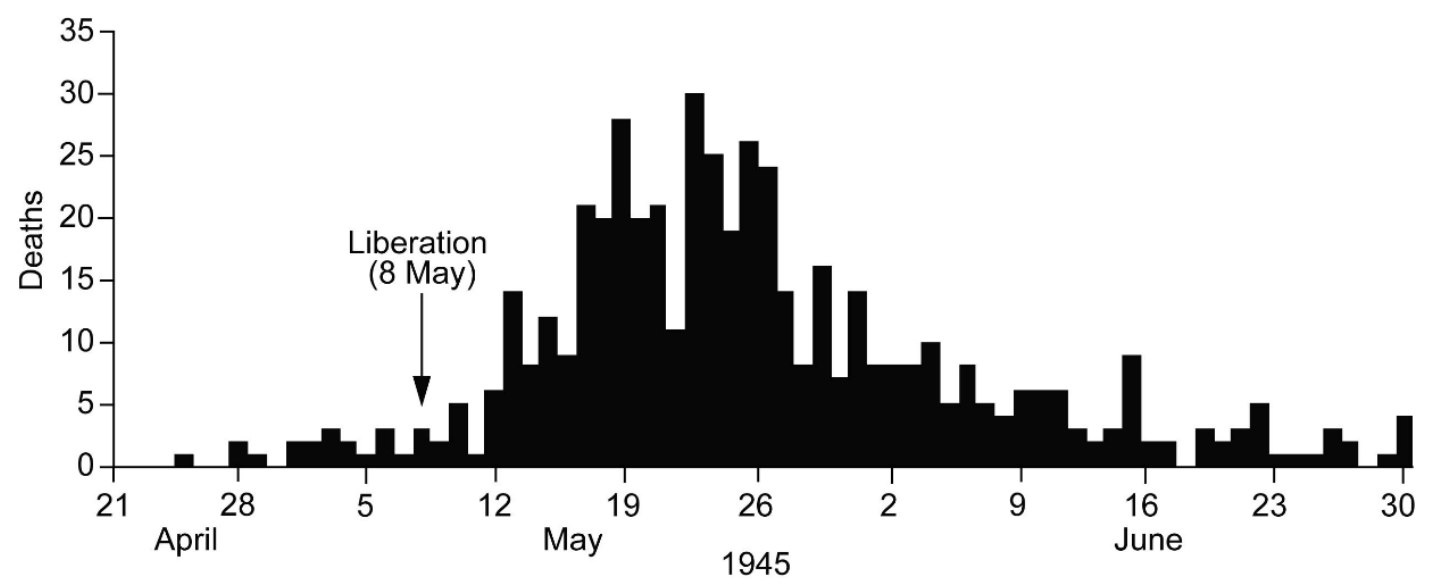

\section{B All causes}

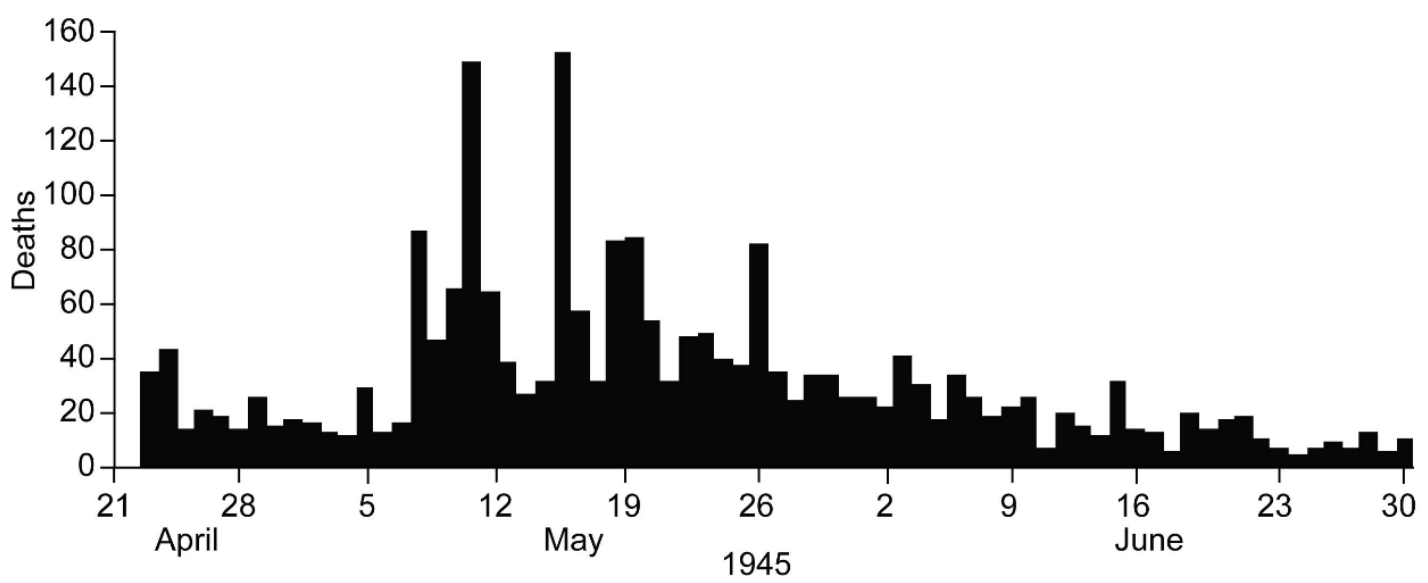

Figure 12. Daily series of deaths by cause in Theresienstadt, April 24 to June 30, 1945. (A) Typhus fever. (B) All causes. Source: data from Prochnik (1945: 33-4, 36-7). 


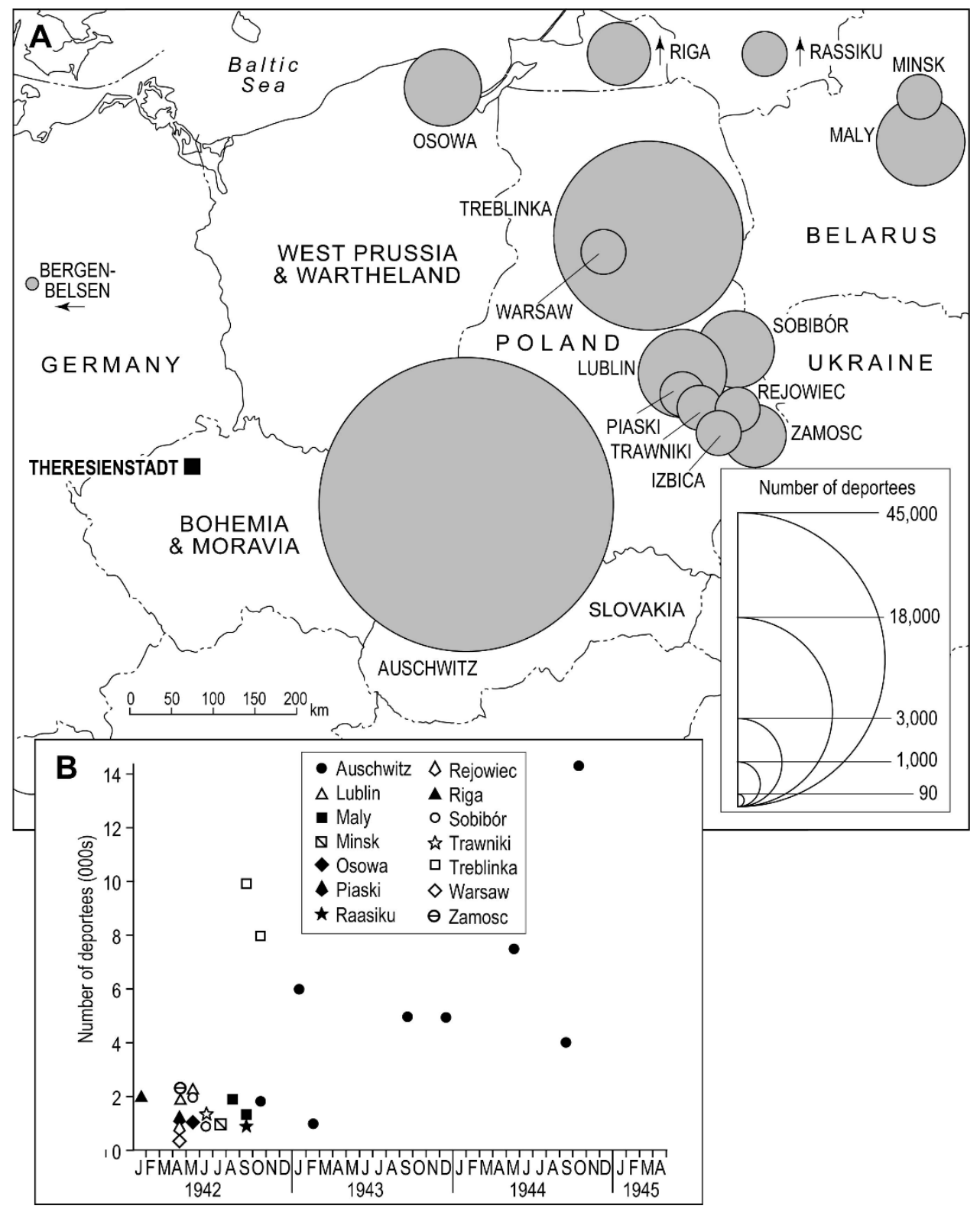

Figure 13. Documented destinations of deportees from Theresienstadt, 1942-45. (A) Total number of deportees by destination over the observation period. (B) Monthly count of deportees by destination. Source: based on data from Archives du Comité International de la Croix-Rouge (ACICR G59/12-369.01, 369.03) and Lederer (1953: 249-51). 

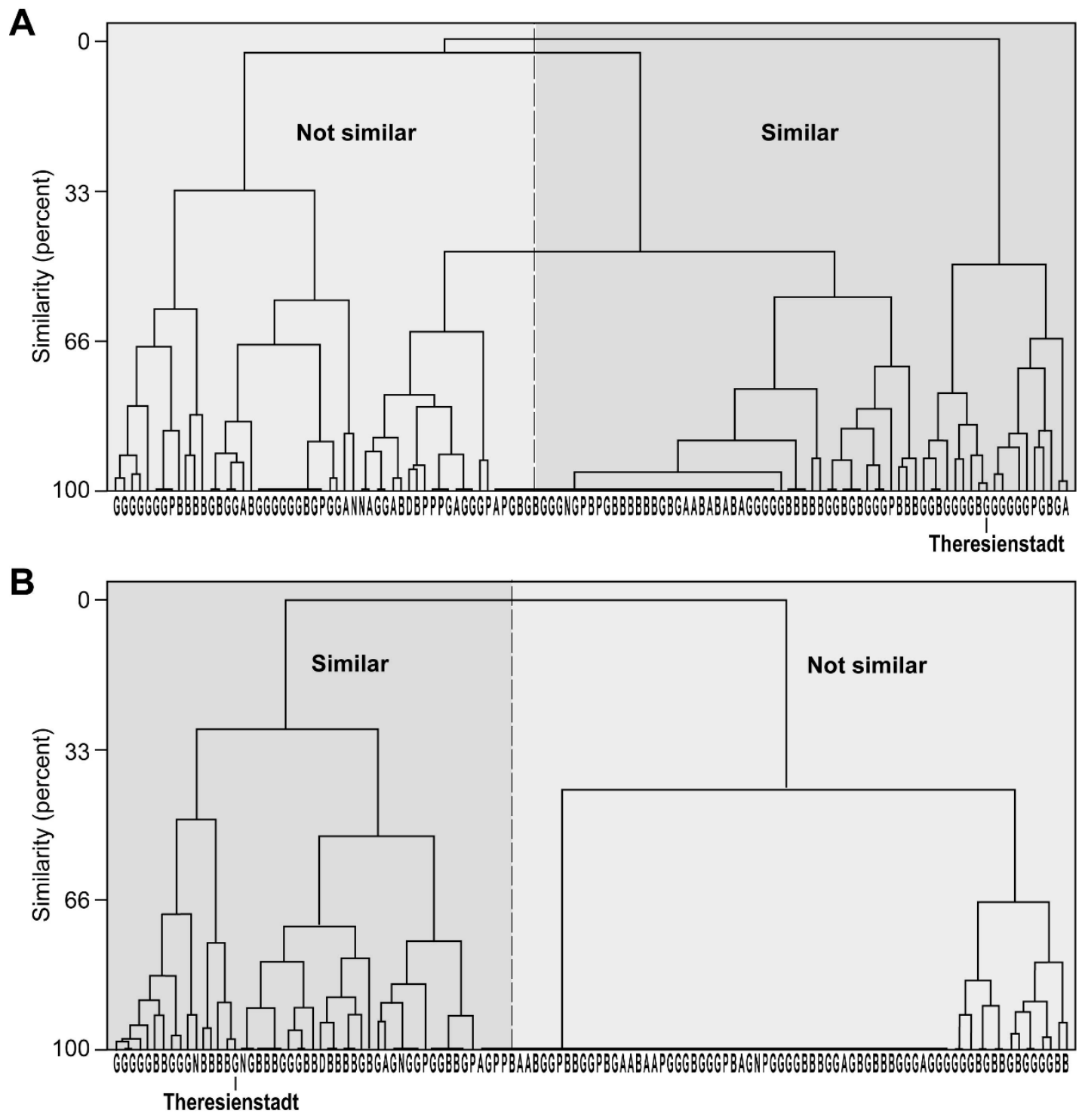

Figure A1. Dendrograms of the similarity between the monthly time series of (i) prisoner arrivals from individual assembly points and (ii) all prisoner arrivals at Theresienstadt, irrespective of place of assembly. Assembly points are letter-coded by country on the horizontal axes $(\mathrm{A}=$ Austria; $\mathrm{B}=$ Bohemia and Moravia; $\mathrm{D}=$ Denmark; $\mathrm{G}=$ Germany; $\mathrm{N}=$ Netherlands; $\mathrm{P}=$ West Prussia and Warthland). (A) Females aged $\geq 61$ years. (B) Males aged 15-45 years. The binary classification of 'similar' and 'not similar' for each demographic group forms the basis of the maps in Figure 7. 


\section{Biographical Note}

Matthew Smallman-Raynor is Professor of Analytical Geography at the University of Nottingham and Andrew Cliff is Emeritus Professor of Theoretical Geography at the University of Cambridge. They have collaborated for some 30 years on the application of geographical methods and techniques to an understanding of the historical geography and demographic impact of infectious diseases. They have jointly authored a number of books, monographs and atlases. Their recent Atlas of Refugees, Displaced Populations, and Epidemic Diseases was published by Oxford University Press in 2018. 


\section{References}

Adler, Hans G. (1955) Theresienstadt. 1941-1945. Das Antlitz einer Zwangsgemeinschaft, Geschichte Soziologie Psychologie. Tübingen: Mohr.

Adler, Hans G. (2017) Theresienstadt 1941-1945: The Face of a Forced Community. New York: Cambridge University Press.

Adler, Reva N., James Smith, Paul Fishman, and Eric B. Larson (2004) “To prevent, react, and rebuild: Health research and the prevention of genocide." Health Services Research 39 (6): 2027-51.

Beinfeld, Solon (1998) "Health care in the Vilna Ghetto." Holocaust and Genocide Studies 12 (1): 66-98.

Blodig, Vojtěch, and Joseph R. White (2012) “Terezín,” in Geoffrey P. Megargee, and Martin Dean (eds.) The United States Holocaust Memorial Museum Encyclopedia of Camps and Ghettos, 1933-1945 - Volume II. Ghettos in German-Occupied Eastern Europe. Bloomington: Indiana University Press: $79-84$.

Browning, Christopher R. (1988) "Genocide and public health: German doctors and Polish Jews, 1939-41. In memory of a friend and colleague in the field of Holocaust studies, Uwe Adam-Radewald, 1940-1987." Holocaust and Genocide Studies 3 (1): 21-36.

Browning, Christopher R. (1995) The Path to Genocide: Essays on Launching the Final Solution (canto edition). Cambridge: Cambridge University Press.

Browning, Christopher R. (2005) "Before the "Final Solution": Nazi ghettoization policy in Poland (1940-1941)" in Ghettos 1939-1945. New Research and Perspectives on Definition, Daily Life, and Survival. Symposium Presentations. Washington, DC: United States Holocaust Museum: 1-13. https://www.ushmm.org/m/pdfs/20050823-ghettos-symposium.pdf (accessed May 23, 2019). 
Brush, Barbara L. (2004) "Nursing care and context in Theresienstadt." Western Journal of Nursing Research 26 (8): 860-71.

Bugnion, François (2003) The International Committee of the Red Cross and the Protection of War Victims. Geneva: International Committee of the Red Cross/Macmillan.

Charlesworth, Andrew (1992) "Towards a geography of the Shoah." Journal of Historical Geography 18 (4): 464-9.

Cliff, Andrew D., Peter Haggett, Matthew R. Smallman-Raynor, Donna F. Stroup, and G. David Williamson (1995) "The application of multidimensional scaling methods to epidemiological data." Statistical Methods in Medical Research 4 (2): 102-23.

Cole, Tim (2003) Holocaust City: The Making of a Jewish Ghetto. New York: Routledge.

Cole, Tim (2004) "Ghettoization," in Dan Stone (ed.) The Historiography of the Holocaust. Basingstoke: Palgrave Macmillan: 65-87.

Epstein, Barbara (2008) The Minsk Ghetto 1941-1943: Jewish Resistance and Soviet Internationalism. Berkeley: University of California Press.

Everitt, Brian S., Sabine Landau, Morven Leese, and Daniel Stahl (2011) Cluster Analysis. Chichester: Wiley.

Farré, Sébastien, and Yan Schubert (2009) "L'Illusion de l'objectif: Le délégué du CICR Maurice Rossel et les photographies de Theresienstadt." Le Mouvement Social 2 (227): 65-83.

Fein, Helen (1997) “Genocide by attrition, 1939-1993. The Warsaw Ghetto, Cambodia, and Sudan: links between human rights, health, and mass death." Health and Human Rights 2 (2): 10-45.

Fischel, Jack R. (1998) The Holocaust. Westport, CT: Greenwood Press.

Gilbert, Martin (2009) The Routledge Atlas of the Holocaust. Fourth edition. London: Routledge. 
Goldman, Brian (1994) "Medicine in the Terezín Ghetto: Commitment to care amidst a concentration camp's horrors." Canadian Medical Association Journal 150 (1): $62-3$.

Gutman, Yisrael (1982) The Jews of Warsaw, 1939-1943. Ghetto, Underground, Revolt. Bloomington: Indiana University Press.

Hájková, Anna (2018) "Medicine in Theresienstadt." Social History of Medicine. Advance article. https://doi.org/10.1093/shm/hky066.

Hoenig, Leonard J., Tomas Spenser, and Anita Tarsi (2004) "Dr Karel Fleischmann: The story of an artist and physician in Ghetto Terezín.” International Journal of Dermatology 43 (2): 129-35.

Horáčková, K., Z. Hrstka, P. Grulich, and E. Hlaváčková (2017) “Infekční choroby a laboratorní diagnostika v podmínkách Židovského ghetta Terezín.” Epidemiologie, Mikrobiologie, Imunologie 66 (1): 8-14.

Horwitz, Gordon J. (2008) Ghettostadt: Łódź and the Making of a Nazi City. Cambridge, MA: Harvard University Press.

International Institute for Holocaust Research (2017) Transports to Extinction: Shoah (Holocaust) Deportation Database. Jerusalem: Yad Vashem. db.yadvashem.org/deportation/search.html?language=en (accessed May 23, 2019).

Intrator, Miriam (2004) "Avenues of intellectual resistance in the Ghetto Theresienstadt: Escape through the central library, books, and reading." Libri 54 (4): $237-46$.

Karas, Joza (1985) Music in Terezín 1941-1945. New York: Beaufort Books.

Knowles, Anne Kelly, Tim Cole, and Alberto Giordano (2014) Geographies of the Holocaust. Bloomington: Indiana University Press.

Král, Adalbert (1947) “An epidemic of encephalitis in the concentration camp Terezín (Theresienstadt) during the winter 1943-1944." Journal of Nervous and Mental Disease 105 (4): 403-13. 
Krug, Etienne G., Linda L. Dahlberg, James A. Mercy, Anthony B. Zwi, and Rafael Lozano, eds. (2002) World Report on Violence and Health. Geneva: World Health Organization.

Lederer, Zdenek (1953) Ghetto Theresienstadt. London: Edward Goldston \& Son Ltd. Lewy, Guenter (1999) “Gypsies and Jews under the Nazis.” Holocaust and Genocide Studies 13 (3): 383-404.

Longacre, McKenna, Solon Beinfeld, Sabine Hildebrandt, Leonard Glantz, and Michael A. Grodin (2015) "Public health in the Vilna Ghetto as a form of Jewish resistance.” American Journal of Public Health 105 (2): 293-301.

Margry, Karel (1992) “"Theresienstadt' (1944-1945): The Nazi propaganda film depicting the concentration camp as paradise." Historical Journal of Film, Radio and Television 12 (2): 145-62.

Margry, Karel (1999) "The first Theresienstadt film (1942)." Historical Journal of Film, Radio and Television 19 (3): 309-37.

Megargee, Geoffrey P., and Martin Dean, eds. (2012) The United States Holocaust Memorial Museum Encyclopedia of Camps and Ghettos, 1933-1945 Volume II. Ghettos in German-Occupied Eastern Europe. Bloomington: Indiana University Press.

Megargee, Geoffrey P., Joseph R. White, and Mel Hecker, eds. (2018) The United States Holocaust Memorial Museum Encyclopedia of Camps and Ghettos, 1933-1945 - Volume III. Camps and Ghettos under European Regimes Aligned with Nazi Germany. Bloomington: Indiana University Press.

Michman, Dan, and Lee J. Schramm (2011) The Emergence of Jewish Ghettos during the Holocaust. New York: Cambridge University Press.

Miron, Guy, ed. (2010) "The Yad Vashem Encyclopedia of the Ghettos during the Holocaust.” Jerusalem: Yad Vashem Publications. 
Modlinger, Martin (2010) “Auf dem Karussell der Geschichte: Das Theresienstädter Kabarett zwischen Historie und Theater." German Studies Review 33 (3): $657-80$.

Prochnik, Robert (1945) Židé v Terezíně: Statistické Sestavení. Prague: Židovské Muzeum v Praze.

Rabinovici, Doron (2011) Eichmann's Jews: The Jewish Administration of Holocaust Vienna, 1938-1945. Cambridge: Polity Press.

Rollin, Henry R. (1988) “Vojtech Adalbert Král.” Psychiatric Bulletin 12 (9): 395-6.

Rovit, Rebecca (2000) "The "Brundibár" project: Memorializing Theresienstadt children's opera." PAJ: A Journal of Performance and Art 22 (2): 111-22.

Rummel, Rudolph J. (1992) Democide: Nazi Genocide and Mass Murder. New Brunswick and London: Transaction Publishers.

Shasha, Shaul M. (2002) "Morbidity in the ghettos during the Holocaust." Harefuah 141 (4): 364-8, 408-9. [In Hebrew]

Smallman-Raynor, Matthew R., and Andrew D. Cliff (2004) War Epidemics: An Historical Geography of Infectious Diseases in Military Conflict and Civil Strife, 1850-2000. Oxford: Oxford University Press.

Smallman-Raynor, Matthew R., and Andrew D. Cliff. (2018) Atlas of Refugees, Displaced Populations and Communicable Disease: Decoding Geographical Patterns and Processes since 1901. Oxford: Oxford University Press.

Stone, Dan (2015) The Liberation of the Camps: The End of the Holocaust and Its Aftermath. London: Yale University Press.

The Goma Epidemiology Group (1995) "Public health impact of the Rwandan refugee crisis: What happened in Goma, Zaire, in July, 1994?” Lancet 345 (8946): $339-44$.

Troller, Norbert (1991) Theresienstadt: Hitler's Gift to the Jews. Chapel Hill, NC: The University of North Carolina Press. 
United States Holocaust Memorial Museum (1996) Historical Atlas of the Holocaust. New York: Macmillan.

United States Holocaust Memorial Museum (2015a) Holocaust Encyclopaedia: Ghettos. Washington, DC: United States Holocaust Museum. www.ushmm.org/wlc/en/article.php?ModuleId=10005059 (accessed May 23, 2019).

United States Holocaust Memorial Museum (2015b) Holocaust Encyclopaedia: Therensienstadt environs, 1944. Washington, DC: United States Holocaust Museum www.ushmm.org/wlc/en/media_nm.php?ModuleId=10007323\&MediaId=16 $\underline{04}$ (accessed May 23, 2019).

United States Holocaust Memorial Museum (2015c) Holocaust Encyclopaedia: Theresienstadt. Washington, DC: United States Holocaust Museum. www.ushmm.org/wlc/en/article.php?ModuleId=10005424 (accessed May 23, 2019).

Weindling, Paul J. (2000) Epidemics and Genocide in Eastern Europe, 1890-1945. Oxford: Oxford University Press.

Weisz, George M., Andrzej Grzybowski, and William R. Albury (2012) "The fate of the Warsaw Ghetto medical faculty." Israel Medical Association Journal 14 (4): 209-13.

Willis, Brian M., and Barry S. Levy (2000) "Recognizing the public health impact of genocide." Journal of the American Medical Association 284 (5): 612-14.

Woolford, Andrew (2010) "The Führer gives the Jews a town: Impression management, homo dramaticus, and bare life in Theresienstadt. Crime, Media, Culture: An International Journal 6 (1): 87-104. 